Yeshiva University, Cardozo School of Law

LARC @ Cardozo Law

2004

\title{
Bankruptcy's Acephalous Moment: Postpetition Transfers Under the Bankruptcy Code
}

David G. Carlson

Benjamin N. Cardozo School of Law, dcarlson@yu.edu

Follow this and additional works at: https://larc.cardozo.yu.edu/faculty-articles

Part of the Law Commons

\section{Recommended Citation}

David G. Carlson, Bankruptcy's Acephalous Moment: Postpetition Transfers Under the Bankruptcy Code, 21 Emory Bankruptcy Developments Journal 113 (2004).

Available at: https://larc.cardozo.yu.edu/faculty-articles/256

This Article is brought to you for free and open access by the Faculty at LARC @ Cardozo Law. It has been accepted for inclusion in Articles by an authorized administrator of LARC @ Cardozo Law. For more information, please contact larc@yu.edu. 


\title{
BANKRUPTCY'S ACEPHALOUS MOMENT: POSTPETITION TRANSFERS UNDER THE BANKRUPTCY CODE
}

\author{
David Gray Carlson*
}

INTRODUCTION

Bankruptcy law's most acephalous' moment is its governance of unauthorized postpetition transfers of property belonging to the bankruptcy estate. On the one hand, Bankruptcy Code $\$ 549$ (a) "avoids" such transfers. ${ }^{2}$ On the other hand, transfers in violation of the automatic stay are, by judge-made law, "void" or "voidable." But if this latter proposition is true, why is $\S 549$ (a) avoidance ever necessary? Is it not a complete superfluity?

Armed with this insight, the Ninth Circuit Court of Appeals all but eliminated $\S 549(\mathrm{a})$ avoidance as a concept governing

* Professor of Law, Benjamin N. Cardozo School of Law.

"Acephalous" means "without a head, without reason." WEBSTER'S THIRD NEW INTERNATIONAL DICTIONARY 14 (1993). I use this term because bankruptcy law has a certain reason to it; nevertheless the Bankruptcy Code has anomalous, "acephalous" moments at war with the overall conceptual structure. For a survey of acephalous moments, see David Gray Carlson, Bankruptcy's Organizing Principle, 26 FlA. ST. U. L. REV. 549 (1999). Hegel mentions acephalous humans in his Logic. GeORg Wilhelm Friedrich Hegel, Hegel's SCIENCE OF LOGIC 799-800 (A.V. Miller trans. 1969) (1830) ("Thus for example the essentiality of the brain for physical man is contradicted by the instance of acephalous individuals, the essentiality of the protection of life and property for the state, by the instance of despotic states and tyrannous governments."). Hegel's point is that reason requires unreason. Because genetic defect is a necessary part of the system, "spirit" cannot be induced from empirical data because we might have before us a defective example. Similarly, law, including bankruptcy law, requires its acephalous moments so that there can always be a gap between positive and natural law.

211 U.S.C. $\$ 549(\mathrm{a})(2000)$. According to $\$ 549(\mathrm{a})$ :

Except as provided in subsections (b) or (c) of this section, the trustee may avoid a transfer of property of the estate-

(1) that occurs after the commencement of the case; and

(2) (A) that is authorized only under section $303(\mathrm{f})$ or 542 (c) of this title; or

(B) that is not authorized under this title or by the court.

See infra text accompanying notes 92-126. 
postpetition transfers. In 40235 Washington Street Corp. v. Lusardi, a buyer at a postpetition foreclosure sale was not permitted to invoke the "bona fide purchaser" defense $e^{5}$ to $\S 549$ (a) avoidance, as the foreclosure sale was already "void" for violating the automatic stay. ${ }^{6}$ The Ninth Circuit reasoned that because the bona fide purchaser defense is not an expressly made exception to the automatic stay in Bankruptcy Code $\S 362$ (b), bona fides could not save the buyer. This was the case even though the debtor filed its bankruptcy petition in bad faith. ${ }^{8}$ Had a bankruptcy trustee avoided this transfer under $\$ 549(\mathrm{a})$, the buyer would have had an opportunity to assert a bona fide purchaser defense, and, in any case, the bad faith dismissal would have revived the transfer. ${ }^{9}$ However, given automatic stay voidness, the good faith postpetition transferee enjoyed no such defense and no such resurrection. ${ }^{10}$ Judge-made law was permitted to erase explicit statutory enactments.

This decision certainly proved that something is rotten in the Denmark of postpetition transfers. To restore order to the postpetition chaos, this Article aims to challenge the judge-made rule that postpetition transfers in violation of the automatic stay are void because any such rule wipes out $\S 549$ (a) of the Bankruptcy Code. Transfers of the bankruptcy estate must be considered voidable, not void, within the purview of $\$ 549$ (a). Such a conclusion is necessary to preserve the defenses listed in $\S 549$ (b), (c), and (d). Further defenses might exist in $\$ 550$ (b) and (e), but these are problematically applied against the trustee in $\S 549$ (a) cases. I propose to show why this is so. The problem with $\S 550$ defenses is that they are defenses to the trustee's cause of action under $\S 550(\mathrm{a}) .{ }^{\prime \prime} \quad$ Yet it is far from clear that $\S 550(\mathrm{a})$ is necessary to

\footnotetext{
329 F.3d 1076 (9th Cir. 2003), cert. denied, 124 S. Ct. 469 (2003).

See 11 U.S.C. $\$ 549$ (c).

- 329 F.3d at 1080.

${ }^{7}$ Id. "Eighteen exceptions ... are listed in section $362(\mathrm{~b}) \ldots$. The text of section
} 362 (a) makes reference to the exceptions listed in section 362 (b) . . . but not to any other exceptions." Id.

${ }^{8} \quad$ Id. at 1078.

9 See 11 U.S.C. $\$ 349$ (b) (1) (B).

10 Lusardi has been strongly endorsed in Singleton v. Abusaad (In re Abusaad), 309 B.R. 895 (Bankr. N.D. Tex. 2004), and Ford v. Loftin (In re Ford), 296 B.R. 537 (Bankr. N.D. Ga. 2003). For a case reaching the same result without relying on Lusardi, see Bustamonte v. Cueva (In re Cueva), 371 F.3d 232 (5th Cir. 2004).

$"$ According to 11 U.S.C. $\$ 550(\mathrm{a})$, 
achieve avoidance under $\$ 549(\mathrm{a})$. It would follow that a postpetition transferee has the defenses listed in $\S 549$ but not the defenses listed in $\$ 550$.

In its attempt to theorize the confusing regime of postpetition transfers, Part I of this Article compares §549(a) avoidance and automatic stay voidness in order to show that the former must trump the latter. Part II considers whether defenses to $\S 549$ (a) avoidance are also defenses against automatic stay voidness and vice versa. Here I criticize the Ninth Circuit's Lusardi opinion, which nearly abolishes $\S 549$ (a) avoidance altogether in favor of an allenveloping automatic stay voidness doctrine. Part III considers the intriguing case of Beeler $v$. Jewell (In re Stanton). ${ }^{12}$ In Stanton, the Ninth Circuit held that postpetition advances to a non-debtor that were guaranteed by a mortgage granted by the debtors could validly encumber the debtors' property interest. ${ }^{13}$ In effect, the debtors were held empowered to make postpetition transfers, regardless of the automatic stay or $\S 549$ (a). Any such transfer, however, was deemed to be junior to the trustee's strong arm lien. Stanton adds a refinement to postpetition transfer law. It stands for the proposition that a debtor's right to a bankruptcy surplus under $\$ 726$ (a) (6) is perfectly alienable. The debtor's conveyance of this surplus, however, cannot interfere with the integrity of the trustee's senior interest. As a prelude to discussing the Stanton case, a short examination of the Ninth Circuit's benighted vocabulary pertaining to postpetition transfers is necessary. ${ }^{14}$

\section{AVOIDANCE UNDER $§ 549$ (a)}

According to $\$ 541(\mathrm{a})$, "[t]he commencement of a [bankruptcy] case ... creates an estate" to be administered by a trustee for the benefit of the general creditors. This simple fact

to the extent that a transfer is avoided under section . . 549 . . the trustee may recover, for the benefit of the estate, the property transferred, or, if the court so orders, the value of such property, from-

(1) the initial transferee of such transfer or the entity for whose benefit such transfer was made ....

12 303 F.3d 939 (9th Cir. 2002), aff'g 248 B.R. 823 (B.A.P. 9th Cir. 2000).

1s Id. at 941 .

14 Perhaps because of its confusing vocabulary, the Ninth Circuit has many more postpetition transfer cases than other circuits. 
implies that, when $D^{15}$ files a bankruptcy petition, $D$ conveys the lion's share of her property rights to a trustee. Bankruptcy is first and foremost a property transfer.

Given the fact that $D$ has conveyed away her property to a trustee, we are already licensed to suspect that $\S 549$ (a) avoidance is likely to be unnecessary and superfluous. If $D$ has already conveyed away most of her property, $D$ is disabled (to use a Hohfeldian word $^{16}$ ) from affecting the trustee's property by transferring it. Suppose, after filing for bankruptcy, $D$ purports to convey prepetition property to $X$. How can $D$ possibly give any title to $X$ when $D$ has no title to give? The trustee needs no avoidance theory to assert better title than $X^{17}$

In fact, $D$ does have some prepetition rights that she could convey postpetition: her right to exempt property and also her right to a bankruptcy surplus under $\S 726$ (a) (6). But these interests are precisely not property of the estate, and so any transfer of them cannot violate the trustee's rights. Furthermore, it appears to be the case that, even after bankruptcy, $D$ has the right to live rent free in her prepetition house. ${ }^{18}$ Presumably this non-trespassory status can be conveyed. But nothing about this conveyance can interfere with

15 In the examples that follow, $D$ is the bankrupt debtor. $A$ is a prepetition transferee. $X$ is a postpetition transferee. $X$ may derive title (if any) from $D$ or possibly from $A$, where $A$ has a power to dispose of $D$ 's property. For example, if $A$ has a valid recorded mortgage, $A$ is sometimes empowered to sell $D$ 's equity (and the bankruptcy estate's equity) to $X$. Two other characters to appear are $P$ and $S$, respectively, parent and subsidiary corporations of $D$.

16 See Wesley N. Hohfeld, Fundamental Legal Conceptions as APPLied in Judicial REASONING 36-38 (Walter W. Cook ed., Yale Univ. Press 1964) (1919).

${ }^{17}$ This is sometimes referred to as using $\$ 544$ (a) defensively. For example, in In $r e$ Loewen Group International, Inc., beneficiaries of a real estate trust claimed to own proceeds of real estate a debtor-in-possession sold. 292 B.R. 522, 525 (Bankr. D. Del. 2003). The court ruled that the bankruptcy estate, not the beneficiaries, owned the underlying real estate and hence the proceeds. Id. at 531. The beneficiaries protested that the debtor-in-possession was making this claim for the first time after the two year statute of limitations under $\$ 546(\mathrm{a})$ had run. Id. at 526. But the court stated the debtor-in-possession could use $\S 544$ (a) (3) defensively without any regard to $\$ 546(\mathrm{a})$. Id. at 528 . In simpler terms, the debtor-inpossession took the real estate into the bankruptcy estate free and clear of the beneficiaries' estate's right.

18 See In re Szekely, 936 F.2d 897 (7th Cir. 1991). See generally Vladimir Elgort, Note, Do Debtors Owe Rent to Their Bankruptcy Trustee for Remaining in the Home After Filing and Prior to Foreclosure, Notwithstanding a Homestead Exemption?, 23 CARDOZO L. REV. 2253 (2002). For the view that the trustee should have the right to rents on the unexamined assumption that the trustee owns the fee simple of the house, see Robert B. Chapman, The Bankruptcy of HaigSimons? The Inequity of Equity and the Definition of Income in Consumer Bankruptcy Cases, 10 АM. BANKR. INST. L. REV. 765 (2002). 
the trustee's own right to use, sell, or lease the house pursuant to $\S 363$. $D$ 's conveyance is simply junior to the rights of the trustee. ${ }^{19}$

Section 549 (a) avoidance becomes relevant if and only if $D$ or some other party has an identifiable power to dispose of the bankruptcy estate, free and clear of the trustee's interest. This follows by definition. To "avoid" presupposes something valid on which the activity of avoidance can operate. ${ }^{20}$ For example, suppose, prior to bankruptcy, $D$ conveys a valid, perfected lien to $A$ and subsequently files for bankruptcy. A now has a power to foreclose on the bankruptcy estate. Of course, this power is automatically stayed. For the moment, assuming away the automatic stay, suppose $A$ uses her power to convey title to $X$. The bankruptcy trustee must, if she can, step forward and recover the property (from $X$ ) that $A$ conveys. ${ }^{21}$ In short, $\S 549$ (a) avoidance presupposes a power, either from state law or the Bankruptcy Code, to convey property of the bankruptcy estate, free and clear of the trustee.

\section{A. The Superfluity of $\$ 549(a)$}

Some examples may be given of unnecessary citations to $\S 549$ (a) when other theories suffice to explain the result. ${ }^{22}$ Misuse of $\S 549$ (a) is not just a formal error. It is substantively important because $\S 549$ (a) is subject to a two-year statute of limitations. ${ }^{23}$ If it

19 One court has tried to justify the use of $\S 549$ (a) in cases where $D$ makes a conveyance on the grounds that the automatic stay does not prevent $D$ from making conveyances of estate property. In re Cueva, 371 F.3d 232 (5th Cir. 2004). Therefore, $D$ would have power to convey. But this overlooks the fact that bankruptcy is a transfer and the debtor is divested of property which is in the bankruptcy estate.

${ }^{20}$ See David Gray Carlson, Hegel's Theory of Quality, 22 CARDOZO L. REv. 425, 441 (2001) ("Since the negative of something always presupposes a something to negate, the negative moment is always a double, 'dia-lectical' one.") (footnote omitted).

${ }^{21} \quad$ Federal Rules of Bankruptcy Procedure 6001 places the burden of proof on the party claiming the validity of the conveyance, not on the trustee, even though the trustee must affirmatively avoid the conveyance in an adversary proceeding. FED. R. BANKR. P. 6001. This carries forward the same rule from $\S 70$ (d) (5) of the Bankruptcy Act of 1898. Bankruptcy Act of 1898 , ch. $541, \S 70$ (d) (5), 30 Stat. 544 (repealed by Bankruptcy Reform Act of 1978, Pub. L. No. 95-598, tit. IV, § 401 (a), 92 Stat. 2549, 2682).

${ }^{22}$ Sometimes $\S 549(\mathrm{a})$ is cited because an unperfected lien is perfected after bankruptcy. E.g., Brandt v. 440 Assocs. (In re S.E. Banking Corp.), 150 B.R. 833 (Bankr. S.D. Fla. 1993). In fact, the security interest is simply subordinated to the trustee's strong arm power.

11 U.S.C. $\S 549$ (d) (2000). 
is conceded that no avoidance theory is implicated, the statute of limitations in $\S 506(\mathrm{~d})$ becomes irrelevant. ${ }^{24}$

The classic example of unnecessary citation to $\S 549$ (a) is Olsen v. Zerbetz (In re Olsen). ${ }^{25}$ In this case, $D$ purported to convey bankruptcy estate property to his son. ${ }^{26}$ In truth, $D$ 's conveyance was ineffective to convey anything to the detriment of the bankruptcy estate because $D$ had no power over it. Nevertheless, the Olsen court found: (1) The conveyance was effective; (2) the trustee had avoidance rights under $\S 549(\mathrm{a})$; (3) the statute of limitations commences to run only upon the trustee's discovery of the conveyance; and (4) the trustee had (fortunately) filed his complaint within two years of discovery-though beyond the two year statute of limitations in $\S 549(\mathrm{~d}) .^{27}$ Olsen implies that the debtor could have conveyed away estate property if the trustee had known and did not bring an avoidance action within the statute of limitations. In fact, the Olsen court should have left $\S 549$ (a) out of the analysis. Rather, it was simply that $D$ 's conveyance could have no possible effect on the bankruptcy trustee's rights. ${ }^{28}$

A similar case is McCord v. Agard (In re Bean). ${ }^{29}$ In this case, a debtor-in-possession, on the very day his chapter 11 case was converted to chapter 7 , conveyed his house without authority to buyers who knew of the bankruptcy. ${ }^{30}$ The trustee, who had obtained the proceeds from the sale, also sought to recover the house under $\S 549(\mathrm{a}){ }^{31}$ The court ruled that because the trustee had received the proceeds, he could not also sue to avoid the

${ }^{24}$ In re Loewen Group Int'l, Inc., 292 B.R. 522 (Bankr. D. Del. 2003) (finding mere assertion of estate ownership not implicated in any statute of limitations). Even if $\S 549$ (d) does not apply, it will be necessary for a federal court to borrow state law statutes of limitations if a third party has taken the bankruptcy estate without court approval. In Burtch v. Ganz (In re Mushroom Transp. Co.), 382 F.3d 325 (3d Cir. 2004), debtor's counsel embezzled estate funds, and the court borrowed a two year statute of limitations for the conversion count and a four year statute for a breach of contract claim. Id. at 338. But for the existence of the contract, the debtor-in-possession fared no better under Pennsylvania law than under $\S 546(d)$. Id.

${ }^{25} 36$ F.3d 71 (9th Cir. 1994).

${ }^{26} \quad I d$. at 72 .

${ }^{27} \quad$ Id. at 73 .

${ }^{28}$ For a similar unnecessary reliance on $\$ 549$ (a), see Burms v. Shelton (In re Shelton), 273 B.R. 116 (Bankr. W.D. Ky. 2002), rev'd sub nom Peoples Bank \& Trust Co. v. Burns, 2004 U.S. App. LEXIS 7553 (6th Cir. Apr. 16, 2004).

29251 B.R. 196 (E.D.N.Y. 2000).

so Id. at 200.

${ }^{31} I d$. 
conveyance of the house, in light of $\S 550(\mathrm{~d}),{ }^{32}$ which provides that "the trustee is entitled to only a single satisfaction." A better way to put this is that, by retaining the proceeds (presumably with bankruptcy court acquiescence), the trustee (and the court) effectively ratified the debtor's unauthorized conveyance, thereby permitting the buyers to stay in possession. Section 549(a) did not apply because the conveyance was ratified after the fact.

A more complicated misuse occurs in United States $v$. Shaltry (In re Home America T.V.-Appliance Audio, Inc.). ${ }^{33}$ In this case, $D$ was a wholly owned subsidiary of $P$, the parent corporation. ${ }^{34} D$ had net operating losses ("NOLs") that could have been used to generate a tax refund in prior years. ${ }^{35} D$ 's creditors filed an involuntary bankruptcy petition against $D .^{36}$ During the gap between the bankruptcy petition and the "order for relief" (i.e., the adjudication of bankruptcy), ${ }^{37} D$ and $P$ entered into an agreement that authorized $P$ to file a consolidated return for the entire corporate group. $^{38}$ As a result, $D$ lost a refund from a prior year that would have enriched $D$ 's bankruptcy estate. $P$, however, paid fewer taxes. After the order for relief, $D$ 's chapter 7 trustee sought to rescind the agreement permitting a consolidated return. ${ }^{39}$ In connection with this attempted rescission, the trustee filed an amended return for $D$, which required the IRS to pay a refund into the bankruptcy estate. ${ }^{40}$

Ultimately, the trustee's entitlement to this refund depended on whether, during the "gap" period, $D$ validly agreed to the consolidated return. ${ }^{41}$ According to $§ 303(\mathrm{f})$ :

Notwithstanding section 363 of this title, ${ }^{[42]}$ except to the extent that the court orders otherwise, and until an order for relief in the case, any business of the debtor may continue to operate, and the debtor

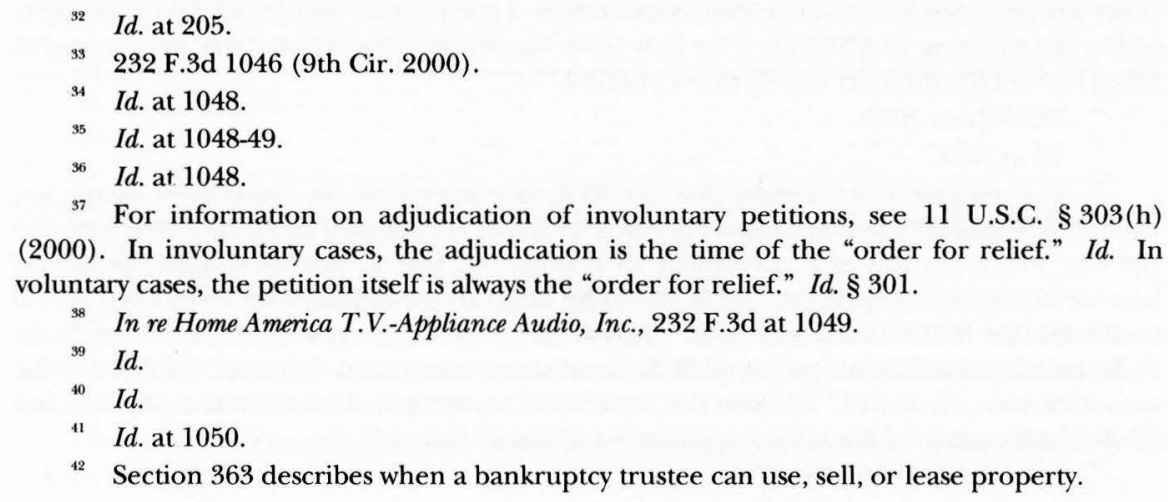


may continue to use, acquire, or dispose of property as if an involuntary case concerning the debtor had not been commenced.

The real question before the court was whether the agreement fell within the operations of $D$ 's business. ${ }^{43}$ If not, then $D$ 's bankruptcy trustee properly filed a new tax return justifying a refund payable to $D$ 's bankruptcy estate.

The Home America court saw the trustee's theory as turning on $\S 549$ (a) avoidance. ${ }^{44}$ The new tax return, however, was filed more than two years after the bankruptcy petition. Accordingly, the trustee's $\S 549$ (a) action was time barred, and the IRS did not owe the refund. ${ }^{45}$ If the statute of limitations in the Internal Revenue Code had been applied, the trustee timely filed for the refund.

The assumptions made by the Home America court are untenable. What property of $D$ did the IRS receive? Arguably it received tax payments from $D$ years before, but these were hardly "postpetition transfers." Nor did the IRS receive the NOL that $D$ should have used to reduce its own tax obligation. In fact, the IRS was harmed because $P$ "received" the NOL. Because $P$ used the NOL, the IRS received less revenue than it would have if $P$ had filed an unconsolidated return. The implication that, but for the statute of limitations, the IRS had to pay ready cash to $D$ 's trustee because $P$ paid fewer taxes is, to say the least, acephalous. ${ }^{46}$ Nevertheless, the court reached the right result for radically the wrong reasons.

Smith v. Mark Twain National Bank (In re Reidy Marketing Co. ( $^{47}$ is another case in which $\S 549$ (a) should have been omitted from the discussion. In Reidy Marketing, $D$ wired money to its bank and

43 Russell v. United States (In re Russell), 927 F.2d 413, 418 (8th Cir. 1991). The Russell court was prepared to find the consolidated return a postpetition transfer of debtor property within the meaning of $\S 549(\mathrm{a})$. The only issue was whether the transfer was unauthorized as being beyond the ordinary course of $D$ 's business. Id.

44232 F.3d at 1050.

$45 \quad$ Id. at 1051.

${ }^{46}$ For another case holding that $D$ 's NOL is property of the bankruptcy estate, see Official Committee of Unsecured Creditors v. PSS S.S. Co. (In re Prudential Lines, Inc.), 928 F.2d 565 (2d Cir. 1991). In this case, an affiliate of $D$ sought to take a "worthless stock" deduction because $D$ 's stock was valueless. $I d$. at 567 . The effect of the affiliate's deduction was that $D$ would lose its NOL tax attribute. Id. The Prudential Lines court viewed the affiliate's tax deduction as an attack on property of the bankruptcy estate and therefore void under the automatic stay. Id. at 574. Because the bankruptcy trustee relied on the automatic stay, not $\S 549$ (a), the statute of limitations apparently was not an issue. Id.

47805 F.2d 278 (8th Cir. 1986). 
obtained a certificate of deposit ("CD"). ${ }^{48}$ This occurred in the gap between an involuntary petition and the order for relief. The bank argued that the $\mathrm{CD}$ was collateral under a prepetition security agreement, concededly a voidable postpetition security interest under $\S 549$ (a), but nevertheless not voidable because the statute of limitations had run under $\S 549(\mathrm{~d}) .^{49}$ The Reidy Marketing court agreed with all of the above, but also found that the bank was estopped from asserting the statute of limitations because it had, by letter, promised to pay the CD shortly after the bankruptcy adjudication. $^{50}$ In fact, the court should have ruled that a bank cannot take a security interest in its own obligation to pay the $\mathrm{CD} .^{51}$ Under state law, the bank had only a setoff right, but because prepetition debt cannot be set off against postpetition debt, ${ }^{52}$ the setoff right failed. ${ }^{53}$ Any reference to $\$ 549(\mathrm{a})$ in this case was superfluous.

Sometimes a debtor-in-possession or bankruptcy trustee transfers property of the estate without court permission. Should these transfers be viewed as valid but voidable, or are they simply non-events? For instance, a debtor-in-possession might grant an ultra vires mortgage or might pay attorneys without court permission. Properly, these unauthorized conveyances are nullities without any reference to avoidance. Rather, the third party in possession of estate property must turn them over under $\S 542$ (a) or, if the property has been converted to the third party's use, pay the value under $\S 542(\mathrm{~b})$. Such a view implies that the two year statute of limitation in $\S 549$ (d) is irrelevant.

Nevertheless, the court in Deckelbaum v. Cooter, Mangold, Tompert $\mathcal{E}$ Chapman $^{54}$ ruled that $\$ 549$ (a) avoidance was required to retrieve unauthorized transfers. ${ }^{55}$ This, in turn, implied a statute of limitations. The Deckelbaum court was quick to find equitable tolling

18 Id. at 293.

49. Id.

50 Id. at 294.

51 See Fireman's Fund Ins. Co. v. Plaza Oldsmobile Ltd., 596 F. Supp. 657, 663 (E.D.N.Y. 1984) (vacated on other grounds); U.C.C. $\$ 9-109$ (10) (2000).

$52 \quad$ E.g., Fireman's Fund Ins. Co., 596 F. Supp. at 657.

53 One bad implication of the Reidy Marketing opinion is that security agreements can overrule $\S 553(\mathrm{a})$, which requires that only countervailing prepetition debts may be set off.

54275 B.R. 737 (D. Md. 2001).

55 Id.; accord Garcia v. Phoenix Bond \& Indemnity Co. (In re Garcia), 109 B.R. 335, 338 (N.D. Ill. 1989). 
of the statute of limitations. More to the point, $\S 549$ (a) was irrelevant to the trustee's right to a turnover, as was the statute of limitations in $\S 549(d) .^{56}$

\section{B. Proper Applications}

Section 549 (a) has a valid purpose when someone is empowered to convey free and clear of the trustee's lien. ${ }^{57}$ Such power may exist under state law or under federal bankruptcy law.

\section{Power Under State Law}

Such a power may exist pursuant to nonbankruptcy law. For example, suppose $A$ has a prepetition security interest in $D$ 's property. In spite of the bankruptcy petition, $A$ holds a foreclosure sale where $X$ is a buyer. Under state law, $A$ has a pre-existing power over $D$ 's equity interest at the time of the bankruptcy petition. The trustee takes $D$ 's equity interest subject to $A$ 's power.

56 See Deckelbaum, 275 B.R. 737; see also Phoenix Amer. Life Ins. Co. v. Devan (In re Merry-Go-Round Enterps., Inc.), 308 B.R. 237 (D. Md. 2004); Scharffenberger v. Billmore (In re Allegheny Health, Educ. \& Research Found.), 313 B.R. 673 (Bankr. W.D. Pa. 2004). In the author's opinion, both courts unnecessarily held unauthorized payment to require $\S 549$ (a) avoidance.

57 A differing view is presented in Darrell W. Dunham, Postpetition Transfers in Bankmuptcy, 39 U. MıAm L. REV. 1 (1984) (denying $\$ 549$ (a) is a true avoidance power).

Some cases are on the borderline. For example, in Whitaker $v$. CIT Group/Equipment Financing, Inc., 304 B.R. 255 (W.D.N.C. 2004), $D$ granted a security interest to $A$ in equipment and then filed for bankruptcy in North Carolina. $D$ then moved the equipment to New Mexico. Id. at 257. Four months later, A's perfection lapsed thanks to former U.C.C. § 9 103(d)(i) (1999). Id. After the lapse, $D$ purported to sell the machines to $X$. Id. at 258. Sensibly, the court ruled that bankruptcy freezes all priorities, so that $A$ retained a valid security interest and the bankruptcy trustee retained $D$ 's equity. Id. at 262 . But some courts are prepared to punish lapsed perfection in the name of punishing secret liens. E.g., Clark v. Valley Fed. Sav. \& Loan Ass'n (In re Reliance Equities, Inc.), 966 F.2d 1338 (10th Cir. 1992); Expeditors Int'l of Wash., Inc. v. Liquidating Trust (In re Schwinn Cycling \& Fitness, Inc.), 313 B.R. 473 (D. Colo. 2004). If this punitive instinct prevails, could the trustee have avoided $D$ 's postpetition transfer under $\S 549(\mathrm{a})$ ? Properly, no. If we treat the bankruptcy trustee as a judicial lien creditor only, this means that $D$ continues to own equity even after the bankruptcy petition. Carlson, supra note 1 , at 552-53. In that case, $D$ has power over the equipment-power to convey good title to $X$. $D$ has no power over the bankruptcy trustee's judicial lien; however, $X$ does receive something when $D$ conveys the machines- $A$ 's security interest. But $X$ cannot take free and clear of the bankruptcy trustee. Accordingly, $X$ should be subrogated to $A$ 's security interest and the equipment itself would still be part of the bankruptcy estate. Notice that $X$ 's security interest is unperfected but valid in $D$ 's bankruptcy because the trustee has no avoidance theory from lapsed perfection. See GRANT GILMORE \& DAVID GRAY GARLSON, GILMORE AND CARLSON ON SECURED LENDING § 6.02[B] (2000). 
Especially if $A$ has knowledge of the bankruptcy, $A$ clearly violates the automatic stay by holding a postpetition foreclosure sale. $^{58}$ Putting the automatic stay aside for the moment, $\$ 549$ (a) becomes necessary to avoid a postpetition transfer by $A$ to $X$.

Continuing to leave automatic stay voidness aside, other examples of power over the bankruptcy estate from state law might be imagined. Suppose that at the time of bankruptcy $D$ is the holder of negotiable instruments or cash. Under state law, $D$ has the power to convey such items to a holder in due course, free and clear of adverse interests. ${ }^{59}$ Since the bankruptcy trustee is a judicial lien creditor against such items, the trustee has an adverse interest that $D$ can destroy by due negotiation. For this reason, if $D$ disposes of cash after her bankruptcy petition, the trustee cannot pursue the cash in the hands of transferees unless they knew of $D$ 's bankruptcy.

\section{Power Under $§ 542(c)$}

The Bankruptcy Code empowers $D$ and others to convey property of the bankruptcy estate free and clear of the trustee. According to $\$ 542$ (c):

Except as provided in section $362(a)(7)^{[60]}$ of this title, an entity that has neither actual notice nor actual knowledge of the commencement of the case concerning the debtor may transfer property of the estate, or pay a debt owing to the debtor, in good faith and other than in the manner specified in subsection (d) of this section, ${ }^{[61]}$ to an entity other than the trustee, with the same effect as

${ }^{58}$ If $A$ is ignorant of the bankruptcy petition, $A$ arguably has an automatic stay defense in $\S 542$ (c). But this proposition is controversial. See infra text accompanying notes 145-47.

One point may be raised that is perhaps obvious. Where $A$ has a valid prepetition security interest, $A$ often moves to lift the automatic stay for lack of adequate protection, or for want of equity or rehabilitative utility. See 11 U.S.C. $\$ 362(d)$. If the stay is lifted, $A$ is free to exercise its power to the detriment of the bankruptcy estate. See id. But, when this power is exercised, is not $A$ transferring estate property in violation of $\S 549(\mathrm{a})$, and may not the trustee avoid the sale? The answer must be that every lifting of the automatic stay implies an authority to foreclose upon property of the estate. This implied authority must be what keeps a subsequent foreclosure sale from violating $\S 549$. This should have been noted in $\S 549$ (a) but was not.

59 U.C.C. $§ 3-306$ (2002).

60 This provision prohibits the manifestation of postpetition setoffs. Such setoff rights, however, are preserved for the benefit of the creditor, who is deemed a secured creditor in the bankruptcy for the amount of the setoff. 11 U.S.C. $\$ 506$ (a).

${ }^{61}$ This subsection pertains to life insurance policies and is not relevant here. 
to the entity making such transfer or payment as if the case under this title concerning the debtor had not been commenced.

Section 542(c) codifies Bank of Marin v. England, ${ }^{62}$ where A, a bank ignorant of the bankruptcy petition, honored $D$ 's prepetition check made to $X$ 's order. ${ }^{63}$ Although the black letter of the Bankruptcy Act required bank liability, Justice William O. Douglas found himself unable to "read these statutory words with the ease of a computer., ${ }^{64}$ He ruled that, given its ignorance of the bankruptcy petition, $A$ was not liable to pay the amount of postpetition checks to the trustee. ${ }^{65}$ Section $542(\mathrm{c})$, then, empowers $D$ to write prepetition or even postpetition checks on the trustee's bank account where the payor bank is ignorant of the bankruptcy proceeding.

Section 549 (a), however, undoes what $A$ has validly done under $\S 542$ (c). This is because $\S 549(\mathrm{a})$ authorizes the trustee to avoid unauthorized conveyances or conveyances that are "authorized only under section $303(\mathrm{f})$ or $542(\mathrm{c})$ of this title." ${ }^{, 66}$ Unless $X$ has a defense to $\S 549$ (a), the trustee may force $X$ to give back what $A$ has validly transferred. ${ }^{67}$

62385 U.S. 99 (1966).

${ }^{63}$ Id. at $100-01$.

${ }^{64} I d$. at 103. Although the majority simply invented $D$ 's power to convey property of the estate, and although a dissenting view by Justice Harlan chastised the majority for violating the intent of Congress, id. at 106 (Harlan, J. dissenting), Congress later showed that the Bank of Marin majority was just fine after all. See 11 U.S.C. $\$ 542$ (c).

${ }^{65}$ Bank of Marin, 385 U.S. at 103.

${ }_{66} 11$ U.S.C. $\$ 549$ (a) (2) (A).

${ }^{67}$ In the case of checks, the payor bank can honor the check and bear no liability. But the payee has, provisionally, received estate funds and, pursuant to $\$ 549$ (a), must return them. See Clendenen v. Van Dyk Oil Co. (In re Buy-Rite Distrib. Co.), 89 B.R. 906 (D. Utah 1988). Defenses may exist, however. Oddly, had a prepetition check been given to a merchant contemporaneous with the sale of goods, and had the check cleared prepetition, the merchant payee could defend the payment as a technical voidable preference, but one defended under the contemporaneous exchange defense of $\$ 547$ (c) (1). The Supreme Court has ruled, however, that, for voidable preference purposes, checks are transfers of property only when they are honored. Barnhill v. Johnson, 503 U.S. 393 (1992). This holding has been extended to postdate the transfer of bank funds until after the bankruptcy petition. Wittman v. State Farm Life Ins. Co. (In re Mills), 176 B.R. 924 (D. Kan. 1994); Franklin v. Kwik Cash of Martin (In $r e$ Franklin), 254 B.R. 718 (W.D. Tenn. 2000). According to $§ 362$ (b) (11), an exception to the automatic stay exists for "the presentment of a negotiable instrument." In Mills, the court ruled that just because the presentment does not violate the automatic stay does not mean that the presenter may keep the proceeds free and clear of the trustee's avoidance right under $\S 549$ (c). 176 B.R. at 928 .

Under the Barnhill court's reasoning, when a debtor postdates the check, a transaction 
This analysis was followed in Dobin v. Presidential Financial Corp. of Delaware Valley (In re Cybridge Corp.). ${ }^{68}$ In Cybridge, $D$ had a prepetition "notification" factoring arrangement with $X$, whereby $X$ would advance eighty percent of the value of a receivable to $D$ and would receive payment directly from $D$ 's customers, who were told to pay $X^{69} \quad D$ filed for chapter 11 and became a debtor-inpossession. $^{70} \quad D$ neglected to tell $X$ of the bankruptcy, and so $X$ continued to lend on $D$ 's postpetition receivables. ${ }^{71}$ Customers of $D$ took the position of $A$; they were authorized by $\S 542$ (c) to make valid payments to $X^{72}$ Because the customers were empowered to pay, $X$ was empowered to receive those payments. ${ }^{73}$ Therefore, the trustee genuinely had to bring a $\S 549$ (a) action against $X$ to undo what $\S 542$ (c) permits. The Cybridge court properly ignored the automatic stay altogether.

One problem presented by Cybridge was that $X$, who was quite innocent of the matter, had no apparent defense on the face of $\S 549$ (a). $X$ was a bona fide purchaser of receivables, but only bona fide purchasers of real estate have a defense from $\S 549$ (a) avoidance. ${ }^{74}$ The Cybridge court, however, hit upon a device to save $X$ from liability. Granted, the first receivable that came in was recoverable from the trustee. But, subsequent thereto, $X$ gave a new advance to $D$ for the next receivable. ${ }^{75}$ This was not a new loan, the

that would have been immune from voidable preference attack is an invalid postpetition transfer when a bankruptcy petition intervenes between the merchant's receipt and the merchant's presentment of the check. 503 U.S. at 398-99. This is undoubtedly a very questionable result.

A different kind of case is presented when $D$ mails $X$ a cashier's check prepetition, which arrives postpetition. A cashier's check is not D's order to her bank to pay but rather is the promise of a non-debtor bank to pay to the order of $X$. So conceived, it would appear that when $D$ mails prepetition, $D$ has "delivered" it to $X$ and has intended to make $X$ the owner. The Ninth Circuit, however, disagreed and found the above transaction to be a postpetition transfer of estate property. Mora v. Vasquez (In re Mora), 199 F.3d 1024 (9th Cir. 1999). Undoubtedly this would be correct for personal checks, but cashier's checks must be conceived differently.

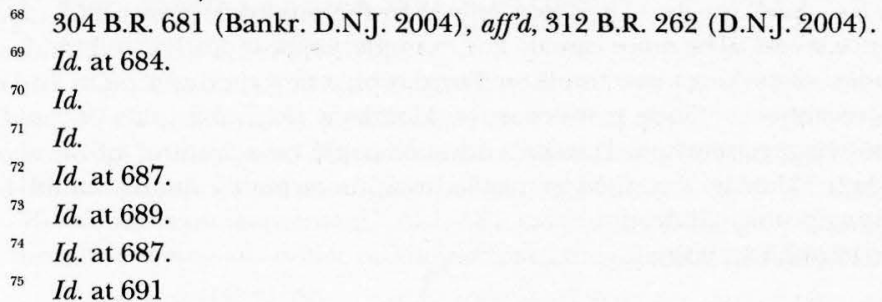


court reasoned. ${ }^{76}$ Rather, it was a return of the first receivable. ${ }^{77}$ Or, to refine the court's theory somewhat, ${ }^{78}$ since $X$ was not returning the exact dollars earlier received, $X$ must have converted those funds to its own use and now owed money to $D .^{79}$ The second loan was therefore actually characterized as payment of the first tort obligation $X$ owed to $D^{80} \quad$ All advances to $D$ were similarly reconceived as payments for earlier wrongs. ${ }^{81}$ Since $X$ advanced to $D$ more than $X$ received from the customers, $X$ 's defense was complete. $^{82}$

One defense against $\S 549$ (a) avoidance is the bona fide purchase defense in $\S 549$ (c). As we shall see, the Ninth Circuit, in 40235 Washington Street Corp. v. Lusardi, ${ }^{83}$ ruled that $\S 549$ (c) is never a defense to automatic stay voidness. In so ruling, the Ninth Circuit heavily emphasized the point that $\S 549$ (c) nowhere appears in $\S 362$ (b), the section that catalogues exceptions to the automatic stay. ${ }^{84}$ Yet neither is $\S 542$ (c) listed in $\S 362$ (b). If the Ninth Circuit is correct that only the exceptions expressly listed in $\S 362$ (b) count

${ }^{76} \quad$ Id. at $691-92$.

7 Id.

${ }^{78}$ The court ruled that money is fungible, the return of new funds was, in effect, a turnover of estate property. Id. In fact, money is not fungible. Every dollar is different, which is why tracing is key in constructive trust cases.

${ }^{79}$ Id.

${ }^{80} \quad I d$. at 692 .

81 Id.

82 See 11 U.S.C. $\$ \mathbf{5 5 0}$ (d) ("The trustee is entitled to only a single satisfaction under subsection (a) of this section"). This recharacterization of $X$ s postpetition advances bears a resemblance to a creditor's defense from voidable preference liability under $\$ 547$ (c) (4). Suppose a creditor has received a voidable preference. If the creditor gives back unsecured new value, the new value constitutes a credit against the voidable preference liability. In Cybridge, advances were secured by additional postpetition receivables, but, as these were voidable under $\$ 549$ (a), the advance could be considered genuinely unsecured. The same result adheres under $\S 547$ (c) (4); where the security interest is for whatever reason voidable, the ostensibly secured advance can be considered the advance of unsecured new value. GILMORE \& CARLSON, supra note 57, § 3.04[B].

Section 547 (c) (4) has a very strict temporal requirement. First, the voidable preference must occur. 11 U.S.C. $\$ 547$ (c) (4). Then and only then the give-back must occur. Id. In Cybridge, the sequence seems to be more casual. For example, suppose $X$ advanced funds on a receivable on Monday. $X$ advances new funds on Tuesday on a new receivable. On Friday, $X$ collects Monday's receivable. Since conversion of Monday's receivable only occured on Friday, it is hard to see precisely how Tuesday's advance could be a "return" of the money purloined on Friday. Making the Cybridge result work in terms of timing would be a formidable accounting problem indeed.

${ }^{83} 329$ F.3d 1076 (9th Cir. 2003).

${ }^{84}$ Id. at 1080 . 
against automatic stay voidness, $\$ 542$ (c) must be viewed as obliterated. Then Lusardi puts itself in contradiction with the Supreme Court's Bank of Marin ${ }^{85}$ opinion. Lusardi's impact is fundamental and far exceeds the negation of $\S 549$ (c).

\section{Power Under $\S 303(f)$}

Another federal source of power to convey free and clear of the bankruptcy estate is D's authority to dispose of property in the "gap" between an involuntary proceeding and the actual adjudication of bankruptcy. When $D$ uses the power of $\S 303(\mathrm{f})$ to dispose of property of the estate, the trustee must avoid the transfer under $\S 549$ (a). X, however, has a very broad defense under $\S 549(\mathrm{~b}){ }^{86}$ Providing the transfer was not on $X$ 's antecedent debt, the trustee may not avoid any conveyance made by $D$ under her $\S 303$ (f) power.

Just as the Ninth Circuit's opinion in Lusardi implicitly wipes out the $\S 549$ (c) defense, it likewise wipes out the $\S 549$ (b) defense. If Lusardi's logic is pushed to its conclusion, the trustee can undo any gap transaction of the debtor because it violates the automatic stay. For instance, suppose $D$ sells inventory to $X$, a buyer in the ordinary course of business, in the involuntary gap period. The sales contract is $X$ 's "act to obtain possession of property of the estate $^{\text {"87 }}$ in violation of the automatic stay. Of course, $D$ was authorized by $\S 303$ (f) to sell to $X$. Yet $\S 303$ (f) is nowhere referenced in $\$ 362(\mathrm{~b})$. Lusardi, which asserts that the only exceptions to the automatic stay are those listed in $\$ 362$ (b), directly threatens Bankruptcy Code governance of the involuntary gap. Obviously, the scope of automatic stay voidness is of the greatest sigrificance, and so to this subject we must now turn.

85 Bank of Marin v. England, 385 U.S. 99 (1966).

86 According to this provision,

(b) In an involuntary case, the trustee may not avoid under subsection (a) of this section a transfer made after the commencement of such case but before the order for relief to the extent any value, including services, but not including satisfaction or securing of a debt that arose before the commencement of the case, is given after the commencement of the case in exchange for such transfer, notwithstanding any notice or knowledge of the case that the transferee has.

${ }^{87} 11$ U.S.C. $\S 362$ (a) (3). 


\section{ThE AUtomatic StAY}

On the surface, there appears to be a conflict between $\S 362$ and $\S 549 .^{88}$

Case law has produced an alternative avoidance theory inspired by the automatic stay. According to purely judge-made law, acts in violation of it are void or perhaps voidable. This concept stems from the notion that equity views as done what ought to be done. ${ }^{89}$ In the case of the automatic stay, the instinct takes a negative turn: Equity views as not done what ought not to be done.

As with $\S 549$ (a), if no one has a power to convey property of the bankruptcy estate once the petition is filed, then any reference to automatic stay voidness is superfluous. If $D$ 's postpetition conveyances are "void," they are not so because of the stay. They are void simply because $D$ has no power to convey property free and clear of the trustee's lien. The point is not just an academic one. The automatic stay can be annulled retroactively. ${ }^{90}$ In contrast, a bankruptcy court has no general discretion to renounce the trustee's ownership because someone with no power over property of the estate purported to convey it away. ${ }^{91}$

The matter changes if $D$ or $A$ has power to convey away the trustee's property, whether under state law, $\$ 542$ (c), or $\S 303(\mathrm{f})$. Only when $D$ or $A$ operates under one of these powers does it make sense to refer to automatic stay voidness. Yet this serves only to exacerbate the point-a judge-made rule is being used to erase powers expressly created by Congress.

Be that as it may, much judicial effort has been wasted trying to figure out whether acts in violation of the automatic stay are "void"

${ }^{88}$ Shaw v. County of San Bernardino (In re Shaw), 157 B.R. 151, 152 (B.A.P. 9th Cir. 1993).

89 $\quad$ See Meddaugh v. Wilson, 151 U.S. 333, 346 (1894) ("It is a cardinal rule of equity that it assumes that that is done which ought to be done ....").

90 Sikes v. Global Marine, Inc., 881 F.2d 176, 178 (5th Cir. 1989).

${ }_{91}$ Ratification of transfers under $\$ \S 363$ (b) or 364 would be exceptions. Here, if the trustee purports to convey estate property, the court is invited to ratify the trustee's unauthorized act after the fact. 2 GILMORE \& CARLSON, supra note 57, § 26.08.

${ }_{92}$ This is how the Supreme Court first put it. Kalb v. Feuerstein, 308 U.S. 433, 438 (1940) ("But if appellants are right in their contention that the federal Act of itself, from the moment the petition was filed and so long as it remained pending, operated, in the absence of the bankruptcy court's consent, to oust the jurisdiction of the state court so as to stay its 
or merely "voidable." 93 By themselves, the words "void" and "voidable" distinguish between what is actual and what is potential. Paradoxically, the "void" act is actually so ${ }^{94}$-already negated, without any affirmative action by the trustee. ${ }^{95}$ A merely "voidable" action has positive existence for the moment, and contains the potential of negation; the trustee, however, must come forward and actually make negative what is for the moment positive but potentially negative.

In choosing between the actually void and the possibly voidable, some courts note that the automatic stay can be annulled. ${ }^{96}$ Annulment must mean that an act allegedly in violation of the stay is curable. If so, it must not be entirely void. Annulment, then, points toward "voidable."

Other courts protest that, if an act in violation of the automatic stay is merely "voidable," and if a trustee does nothing to avoid it, the act becomes valid after bankruptcy. Fearing that wrongdoers will get away with murder under such a view, these courts proclaim acts in violation of the stay to be non-events $a b$ initio. ${ }^{98}$ Treating a conveyance in violation of the stay as void shifts the burden to the wrongdoer to validate what is otherwise an actual non-event. ${ }^{99}$

power to proceed with foreclosure, to confirm a sale, and to issue an order ejecting appellants from their farm, the action of the Walworth County Court was not merely erroneous but was beyond its power, void, and subject to collateral attack."). Of course, if the state court's action is subject to collateral attack, it must be something more than void prior to that attack.

${ }_{93}$ One court recently suggested that the choice is "between 'void'/'voidable,' on the one hand, and 'avoidable,' on the other." Ford v. Loftin (In re Ford), 296 B.R. 537, 546 (Bankr. N.D. Ga. 2003) (emphasis omitted).

${ }_{94}$ This is an oddly Hegelian notion-what is actual is the disappearance of appearance. See generally John F. HoffMeyer, THE AdVEnT OF FREEdOM: THE PRESENCE OF THE FUTURE IN HEGEL's LOGIC (1994) (explicating Hegel's actuality).

${ }_{95}$ Sikes, 881 F.2d at 178 ("By strict definition that which is void is nugatory and of no effect and cannot be cured; that which is voidable may be either voided or cured.").

$96 \quad 11$ U.S.C. $\$ 362(d)$.

${ }^{97}$ Sikes, 881 F.2d at 178 ("The power to annul authorizes retroactive relief even unto the date of the filing of the petition giving rise to the automatic stay. The power to annul authorizes the court to validate actions taken subsequent to the impressing of the section 362(a) stay."); In re Williams, 257 B.R. 297, 301 (Bankr. W.D. Mo. 2001); In re Oliver, 38 B.R. 245, 248 (Bankr. D. Minn. 1984).

${ }_{98} 40235$ Wash. St. Corp. v. Lusardi, 329 F.3d 1076, 1082 (9th Cir. 2003); Schwartz v. United States (In re Schwartz), 954 F.2d 569, 571 (9th Cir. 1992).

99 See Soares v. Brockton Credit Union (In re Soares), 107 F.3d 969, 976 (1st Cir. 1997); Donna Renee Tobar, The Need for a Uniform Void Ab Initio Standard for Violations of the Automatic Stay, 24 WhitTier L. REv. 3, 25 (2002); Timothy Arnold Barnes, Note, The Plain Meaning of the Automatic Stay in Bankruptcy: The Void/Voidable Distinction Revisited, 57 OHIO ST. L.J. 291, 315-16 
In truth, the semantics of negativity has proven unhelpful in working out the ultimate law of the automatic stay. ${ }^{100}$ Even courts stuck with "voidable" have found that actions in violation of the stay are simply "void" without any further action by the trustee. ${ }^{101}$ Courts that embrace "void" nevertheless find actions curable. ${ }^{102}$

Casting aside the semantic debate, a point must be emphasized, and emphasized strongly. The voidness doctrine nowhere appears in the Bankruptcy Code. It is strictly judge-made-the extension of a principle of equity, which holds as (not) done what ought (not) to be done. The Supreme Court has decreed that general principles of equity not be used to overcome express provisions of the Bankruptcy Code. ${ }^{103}$ I suggest this is precisely what happened in the Lusardi case, where the Ninth Circuit used automatic stay voidness, an equitable doctrine, to erase the bona fide purchaser defense in $\S 549$ (c). This is not to say that the voidness doctrine is wrong. It is only to say that it should stop short of eliminating provisions like $\S 303(\mathrm{f})$, $\S 542(\mathrm{c})$, or $\$ 549(\mathrm{~b})-(\mathrm{d})$. But since these provisions

(1996).

Lifting the automatic stay does not inherently cure acts taken earlier in violation of it. In Soares, $A$ sued to foreclose a mortgage and requested a judgment of foreclosure from state court. In re Soares, $107 \mathrm{~F} .3 \mathrm{~d}$ at 972 . Before the court could act, $D$ filed for bankruptcy. Id. The court, ignorant of the bankruptcy, entered a judgment of default. $A$ then moved to lift the stay. Id. The motion was granted. Id. A held a foreclosure sale where $A$ was the buyer. $I d$. Worried about the voidness of the judgment of foreclosure, $A$ moved for retroactive relief. Id. A served papers on $D$ 's attorney, but not on $D$. Id. The bankruptcy court granted retroactive relief. Id. With new counsel, $D$ moved the bankruptcy court to reconsider the grant of retroactive relief and to avoid the foreclosure sale. Id. The bankruptcy court denied D's motions. Id. at 972-93. The court of appeals, however, reversed, ruling that it was an abuse of discretion to grant annulment to $A$, where $A$ knew of the bankruptcy proceeding and failed to warn the state court that a default judgment would violate the automatic stay. Id. at 978. Apparently, $A$ should have returned to the state court after the stay was lifted so that a proper default judgment could be entered.

100 This is so as the Sixth Circuit recognized, in suggesting the phrase "invalid" but curable. Easley v. Pettibone Mich. Corp., 990 F.2d 905, 909 (6th Cir. 1993); see also In re Abusaad, 309 B.R. 895, 899 (Bankr. N.D. Tex. 2004) ("One must not bog down too much in the 'void' v. 'voidable' contest. Regardless of the label placed on the effect of an action taken in violation of the stay, it is clear that such an action is invalid and of no effect unless and until the action is made valid by subsequent judicial action annulling the automatic stay.").

${ }^{101}$ Elbar Invs., Inc. v. Pierce (In re Pierce), 272 B.R. 198, 205-20 (Bankr. S.D. Tex. 2001).

${ }^{102}$ In re Schwartz, 954 F.2d at 573.

${ }^{103}$ United States v. Noland, 517 U.S. 535, 536 (1996) (holding courts may not use equitable subordination to amend the express statutory priorities in the Bankruptcy Code); Norwest Bank Worthington v. Ahlers, 485 U.S. 197, 206 (1988) (“[W] hatever equitable powers remain in the bankruptcy courts must and can only be exercised within the confines of the Bankruptcy Code."). 
nearly exhaust the possibilities for postpetition transfers valid against the trustee, we can summarize by saying that, insofar as the Bankruptcy Code is concerned, automatic stay voidness is completely inappropriate in any case involving a postpetition transfer.

\section{DEFENSES}

Postpetition avoidance presupposes a power in $D$ or $A$ to dispose of the bankruptcy estate in spite of the trustee's property rights in the bankruptcy estate. When this power exists, the trustee must affirmatively avoid the transfer under $\$ 549$ (a) alone. Any assertion of automatic stay voidness eliminates the role of $\$ 549$ (a) from the Bankruptcy Code.

There are at least five defenses to $\S 549$ (a) avoidance. But do they also constitute defenses to automatic stay voidness, if that doctrine is insisted upon? Two defenses exist to the automatic stay. ${ }^{104}$ Are these also defenses to $\S 549$ (a) avoidance? On this the courts are sharply divided. In my view, every defense should apply everywhere against $\S 549$ (a) avoidance and automatic stay voidness. The court-made doctrine of voidness should not be permitted to eclipse any express provision of the Bankruptcy Code protecting postpetition transferees.

\section{A. Bona Fide Purchases of Real Estate}

Section 549 (c) is the defense which, I maintain, the Ninth Circuit has written out of the Bankruptcy Code in 40235 Washington Street Corp. v. Lusardi, ${ }^{105}$ together with $\S 303(\mathrm{f})$ and $\S 542(\mathrm{c})$. According to $§ 549(\mathrm{c})$ :

The trustee may not avoid under subsection (a) ... a transfer of real property to a good faith purchaser without knowledge of the commencement of the case and for present fair equivalent value unless a copy or notice of the petition was filed, where a transfer of such real property may be recorded to perfect such transfer, against whom applicable law permits such transfer to be perfected, could not acquire an interest that is superior to the interest of such good faith

10411 U.S.C. $\$ 362$.

105329 F.3d 1076 (9th Cir. 2003). 
purchase. A good faith purchaser without knowledge of the commencement of the case and for less than present fair equivalent value has a lien on the property transferred to the extent of any present value given, unless a copy or notice of the petition was so filed before such transfer was so perfected. ${ }^{106}$

Because $\S 549$ (c) is a defense, it is applicable only if the trustee needs to avoid a conveyance. The trustee only needs to avoid a conveyance if someone has the power, under state law or the Bankruptcy Code, to make the conveyance. Then, and only then, is it ever necessary to invoke $\S 549$ (a) and (c).

For the classic example of a $\S 549$ (c) defense, suppose $D$ grants a valid mortgage on real estate to $A$. In spite of the automatic stay, $A$ sells to $X$, who is a bona fide ${ }^{107}$ purchaser $^{108}$ for "present fair equivalent value" ${ }^{\text {"109 }}$ within the meaning of $\S 549(\mathrm{c})$. Here is a

106 Prior to the 1984 amendments, the power of $D$ to convey the trustee's real estate to bona fide purchasers did not exist if the real estate was located in the same county where the bankruptcy court was located. Tavormina v. Brummer (In re Centre de Tricots de Gaspé), 782 F.2d 905, 907 (11th Cir. 1986); Dunham, supra note 57, at 86-87.

${ }^{107}$ According to some courts, if $X$ has reason to know of $D$ 's bankruptcy, $X$ cannot be a good faith purchaser. Szybist v. McKean County Tax Glaim Bureau (In re Taft), 262 B.R. 55, 61 (Bankr. M.D. Pa. 2001); D'Alfonso v. A.R.E.I. Inv. (In re D'Alfonso), 211 B.R. 508, 513 (Bankr. E.D. Pa. 1997). Of course, anyone who allows property taxes to go on unpaid is a likely candidate for bankruptcy, so that the Taft court is perilously close to saying that $X$ is on inquiry notice of $D$ 's bankruptcy. That is, $X$ is charged with the knowledge of a successful inquiry if $X$ makes no inquiry at all.

${ }_{108}$ A purchaser must also record the foreclosure deed. Commonwealth Mortg. Co. of Am. v. Konowitz (In re Konowitz), 905 F.2d 55, 59 (4th Cir. 1990); Walker v. Cal. Mort. Serv. (In re Walker), 861 F.2d 597, 600 (9th Cir. 1988); In re Ward, 837 F.2d 124 (3d Cir. 1988); In re Major, 218 B.R. 501, 506 (Bankr. W.D. Mo. 1998); see also William J. Rochelle III \& Gwen Feder, Unauthorized Sales of a Debtor's Property: The Rights of a Purchaser Under Section 549 of the Bankruptcy Code, 57 AM. BANKR. L.J. 23, 45-46 (1983). According to the text of $\S 549$ (c), if $D$ files notice of the bankruptcy in the real estate records before $X$ "perfects," $X$ cannot claim the defense of $\S 549(c)$.

In Ward, $X$ was bona fide but had not perfected. 837 F.2d at 125. But neither had the bankruptcy trustee filed notice of the bankruptcy in the local real estate records. See id. Because bona fides are properly tested at the moment of investment (not the moment of recordation), it should still have been open for $X$ to perfect and preserve his defense. Section 549 (c) does not exactly say that $X$ must perfect. It says only that the defense depends on the fact that no bankruptcy petition has been recorded in the real estate records prior to perfection. Id. at 126. Apparently, where neither side has recorded, the defense is tentatively valid, according to $\S 549$ (c)'s literal meaning, though the parties are in a "race to the court house." Id. at 126-27. If the trustee wins the race, the defense is destroyed.

All of this is acephalous. Given that $A$ 's mortgage is of record, why does it matter if $X$ records or not, so long as $X$ is in good faith at the time of purchase?

${ }^{109}$ Some courts have read "present fair equivalent value" to mean bid-in buyers are excluded. Shaw v. County of San Bernardino (In re Shaw), 157 B.R. 151, 154 (B.A.P. 9th Cir. 
genuine case in which $X$ should prevail because $A$ had a valid power over the bankruptcy estate. Nevertheless, it is sometimes held that this same transaction violates the automatic stay. If $X$ 's deed is void or voidable for this reason, then the trustee recaptures the conveyed property under $\S 542$ (a) without any reference to $\S 549$ (a) or (c).

We have before us an acephalous moment. In fact, $\$ 549$ (c) should be a defense to the automatic stay-part of $\S 362$ (b) - as well as a defense to $\S 549$ (a) avoidance. It was not listed as an exception in $\S 362$ (b), and this has motivated the Ninth Circuit, in a sublimely egregious case, to rule that, where the automatic stay has been violated, $\S 549(\mathrm{c})$ never helps a bona fide purchaser at a postpetition foreclosure sale. ${ }^{110}$

In Lusardi, $D$, a newly created entity, bought real estate encumbered by superpriority tax liens. ${ }^{111}$ It promptly made a bad faith bankruptcy filing. ${ }^{112}$ Although the county had received a faxed copy of $D$ 's bankruptcy petition, it nevertheless held a foreclosure sale where $X$ was the buyer. $X$ had no knowledge of the bankruptcy. Later, the county refused to issue a deed to $X{ }^{113} D$ filed notice of the bankruptcy proceeding in the county real estate records, and soon thereafter $D$ 's chapter 11 proceeding was dismissed. ${ }^{114}$

1993); In re Major, 218 B.R. at 505; Purnell v. Citicorp Homeowners Servs., Inc. (In re Purnell), 92 B.R. 625, 630 (Bankr. E.D. Pa. 1988); In re Powers, 88 B.R. 294 (Bankr. D. Nev. 1988). Other courts, borrowing from BFP v. Resolution Trust Corp., 511 U.S. 531 (1994), have ruled that any price received at a court-supervised foreclosure sale is per se fair equivalent value. T.F. Stone Co. v. Harper (In re T.F. Stone Co.), 72 F.3d 466, 470-72 (5th Cir. 1995). But see In re D'Alfonso, 211 B.R. at 513 (BFP is limited to mortgage foreclosures of real estate). Still other courts impose on $X$ the burden of showing that the price paid was actually fair. Ford $v$. Loftin (In re Ford), 296 B.R. 537, 550 (Bankr. N.D. Ga. 2003). For an argument against extending $B F P$ to $\S 549$ (c) cases, see Janet A. Flaccus, Pre-Petition and Post-Petition Mortgage Foreclosures and Tax Sales and the Faulty Reasoning of the Supreme Court, 51 ARK. L. REV. 25 (1998). Prior to the 1984 amendments, buyers at "judicial sales" were protected whether or not they paid value. Rochelle \& Feder, supra note 108, at 49-51.

110 Lusardi, 329 F.3d at 1080.

111 Id. at 1078.

112 The owners of $D$ suffered from the "new debtor syndrome"-formation of an entity for the sole purpose of placing it in bankruptcy proceedings. See id.; see also Udall v. Fed. Deposit Ins. Corp. (In re Nursery Land Dev., Inc.), 91 F.3d 1414, 1415 (10th Cir. 1996); Laguna Assoc. Ltd. v. Aetna Cas. \& Sur. Co. (In re Laguna Assoc. Ltd.), 30 F.3d 734, 738 (6th Cir. 1994). For a case awarding sanctions against an attorney for filing a "new debtor" chapter 11 petition, see In re St. Stephen's 350 E. 116th St., 313 B.R. 161 (Bankr. S.D.N.Y. 2004).

113 Presumably the county feared issuance of the deed was a violation of the automatic stay. But see Rodgers v. County of Monroe (In re Rodgers), 333 F.3d 64, 67-68 (2d Cir. 2003) (finding where bankruptcy petition followed foreclosure sale, issuance of deed after bankruptcy did not violate automatic stay).

114 According to the district court, the bankruptcy court dismissed the chapter 11 
Immediately after the bad faith dismissal, $X$ commenced a "quiet title" action in state court. ${ }^{15} D$ responded with a federal complaint, alleging that $X$ had no title because the foreclosure sale was "void" for violating the automatic stay. ${ }^{116}$ In the federal action, $X$ successfully obtained an abstention order. ${ }^{117}$ The state court then ruled that $X$ had no title because of automatic stay voidness. ${ }^{118} X$ responded by finally answering $D$ 's federal complaint. Although res judicata should have applied, the District Court nevertheless reached the merits and decided for $D$. Finding that $\S 549$ (c) is an inherent exception to the automatic stay, the District Court found that $X$ did not qualify for the defense for two reasons. First, $X$ never recorded a deed and so did not qualify as a bona fide purchaser within the meaning of $\S 549$ (c). ${ }^{119}$ Second, $X$ paid too little to constitute a "present fair equivalent value."

On appeal, the Ninth Circuit ruled that $\$ 549$ (c) could never be a defense when automatic stay voidness was the operative theory. ${ }^{121}$ The Ninth Circuit observed that bona fide purchase under $\S 549(\mathrm{c})$ is not mentioned in $\S 362(\mathrm{~b})$, and therefore the $\$ 549$ (c) defense could not be asserted against automatic stay "voidness."

proceeding because $D$ "had no viable reorganization plan." 40235 Wash. St. Corp. v. Lusardi, 177 F. Supp. 2d 1090, 1095 (S.D. Cal. 2001).

${ }^{115}$ Id. at $1095,1107$.

116 Id. at 1095.

11740235 Wash. St. Corp. v. Lusardi, 976 F.2d 587 (9th Cir. 1992).

118177 F. Supp. 2d at 1096 ("In 1996, the California Court of Appeals heard Lusardi's suit against Washington Street. The court, relying on the Ninth Circuit's Schwartz opinion, held that Lusardi's tax deed was void, not voidable."). Here the court refers to In re Schwartz, 954 F.2d 569 (9th Cir. 1991).

119 See supra notes 105-110.

${ }^{120} 11$ U.S.C. $\$ 549$ (c) (2000). The last sentence of $\S 549$ (c) reads: "A good faith purchaser without knowledge of the commencement of the case and for less than present fair equivalent value has a lien on the property transferred to the extent of any present value given, unless a copy or notice of the petition was so filed before such transfer was so perfected." $X$ could not prevail under this section because $D$ filed notice of the bankruptcy before $X$ did.

12140235 Wash. St. Corp. v. Lusardi, 329 F.3d 1076, 1080 (9th Cir. 2003).

${ }_{122}$ Id.; see also In re Ward, 837 F.2d 124 (3d Cir. 1988); Ford v. Loftin (In re Ford), 2003 Bankr. LEXIS 902, at *21 (Bankr. N.D. Ga. Aug. 1, 2003); Glendenning v. Third Fed. Sav. Bank (In re Glendenning), 243 B.R. 629, 633-34 (Bankr. E.D. Pa. 2000); Smith v. London (In re Smith), 224 B.R. 44, 47 (Bankr. E.D. Mich. 1998); In re Powers, 88 B.R. 294 (Bankr. D. Nev. 1988). The court in Elbar Investments, Inc. v. Pierce (In re Pierce), 272 B.R. 198, 205-20 (Bankr. S.D. Tex. 2001), so held, even in the teeth of In re T.F. Stone Co., 72 F.3d 466 (5th Cir. 1995). In Stone, a county with a tax lien made a postpetition foreclosure sale to itself as buyer. In re 
I contend that, by this reasoning, the Ninth Circuit wrote not just $\S 549$ out of the Bankruptcy Code, but $\S 303$ (f) and $\S 542$ (a) as well, suffocating these sections in the powerful vacuum of automatic stay voidness. By so doing, it allowed a judge-made rule to cancel the express statutory commands of Congress.

Anticipating this critique, the Lusardi court asserted that it left legitimate ground on which $\$ 549$ (a) could stand. According to the court, " $[t]$ he purpose of section $549 \ldots$ is to provide a just resolution when the debtor himself initiates an unauthorized postpetition transfer." ${ }^{123}$ Yet, based on what has been said, it should

T.F. Stome Co., 72 F.3d at 467 . It successfully asserted a $\$ 549$ (c) defense against a $\$ 549$ (a) avoidance action. Id. at 472 . The Elbar court found Stone to be inapposite because the trustee in Stone did not assert an automatic stay theory. 272 B.R. at 205 ("Nowhere in Stone is there any indication that the forced sale in that case violated Bankruptcy Code $\S 362$. The decision does not indicate whether.the creditor had obtained relief from the automatic stay or whether the tax sale in question simply was not prohibited by the stay for some other reason."). In an accompanying footnote, Judge Steen speculated, "[t] he stay might not have applied to the property or might have terminated by operation of law." Id. at $205 \mathrm{n} .11$. Yet logically the automatic stay must have been there. If the automatic stay had been lifted, then the taxing authority was authorized to sell. If the stay had ended because the proceeding had ended, then the trustee could not have had a $\$ 549$ (a) theory to assert. The statute of limitations terminates the trustee's cause of action once the bankruptcy case is closed. 11 U.S.C. $\$ 549$ (d) (2). It has been suggested that Stone involved postpetition property tax liens, the creation of which did not violate the automatic stay. In re D'Alfonso, 211 B.R. 508, 518 (Bankr. E.D. Pa. 1997); see 11 U.S.C. $§ 362$ (b) (11). This is wrong for two reasons. First, prior to 1994 , postpetition property tax liens were void under the automatic stay. City of Farmersbranch v. Pointer (In re Pointer), 952 F.2d 82 (5th Cir. 1992). The 1994 amendments, which added $\S 362$ (b)(11), did not apply to the case. Second, even if attachment did not violate the stay, the foreclosure sale surely did. Therefore, this suggestion must be rejected.

Notice Stone is not a case where $\S 542$ (c) applies, because $A$ had no prepetition power to sell $D$ 's property. $A$ 's lien arose strictly postpetition. In fact, it would appear that in the Fifth Circuit, Stone establishes the $\$ 549$ (c) defense against an automatic stay theory.

Confusingly, in Lilly $v$. Federal Deposit Ins. Corp. (In re Natchez Corp.), 953 F.2d 184 (5th Cir. 1992), the Fifth Circuit seemed to suggest that the only remedy for undoing a postpetition transfer was $\S 549$ (a) - not the automatic stay. More narrowly, Natchez holds that a private creditor has no standing to undo a postpetition transfer under $\$ 549$. Id. at 187 .

${ }^{123} 329$ F.3d at 1081. Judge Reinhart picks up a point made in In re Schwartz, 954 F.2d 569 (9th Cir. 1991):

[A] straightforward analysis of section 549 reveals that it is not intended to cover the same type of actions prohibited by the automatic stay nor rendered moot by section 362's voiding of all automatic stay violations. Section 549 applies to unauthorized transfers of estate property which are not otherwise prohibited by the Code. In most circumstances, section 549 applies to transfers in which the debtor is a willing participant....

Section 362's automatic stay does not apply to sales or transfers of property initiated by the debtor. Thus, section 549 has a purpose in bankruptcy beyond the potential overlap with section 362 . In other words, the automatic stay can void any violation and still leave section 549 with a valid and important role in bankruptcy. 
be apparent that, except for involuntary cases, where $\S 303(\mathrm{f})$ empowers $D$ to dispose of property prior to the bankruptcy adjudication, or perhaps in cases involving commercial paper, $D$ never has power to convey property free and clear of the trustee's lien. The ground reserved for $\S 549(\mathrm{a})$ is almost a null set. Accordingly, the Ninth Circuit is guilty of largely reading $\$ 549$ (a) straight out of the Bankruptcy Code.

Because a debtor has power under $\S 303(f)$ to convey property free and clear of the trustee's lien, $\S 549$ (a) has a utility, but is it one limited to involuntary gap cases? Such a claim must fail. Any attempt by $D$ to use her $\S 303(f)$ power constitutes a violation of the automatic stay-an act to "exercise control over property of the estate." ${ }^{124}$ Furthermore, $X$ violates the stay by receiving property of the estate. ${ }^{125}$ Since the premise in Lusardi is that all acts are barred unless specifically mentioned in $\S 362$ (b), Ninth Circuit logic requires the absolute erasure of $\S 303(\mathrm{f})$. This cannot be given as an example of genuine territory in which $\S 549$ might still operate. ${ }^{126}$ At best, $\S 549$ has utility only in commercial paper cases.

Section 549 exists as a protection for creditors against unauthorized debtor transfers of estate property. Although there are circumstances where section 362 overlaps section 549 and renders it unnecessary, this overlap falls far short of rendering section 549 meaningless....

Id. at 573-74 (citations omitted).

${ }^{124} 11$ U.S.C. $\$ 362$ (a) (3).

195 Id.

${ }^{126}$ If Lusardi is wrong, then $X$ may assert the defense of $\S 549$ (c). This may mean that $A$ has violated the automatic stay, but the trustee has no remedy against $X$. What are the trustee's rights against $A$ ?

It can be observed without controversy that, first, $A$ has received proceeds of estate property, which it holds in trust for the bankruptcy trustee. 11 U.S.C. $\$ 541$ (a) (6). Accordingly, the trustee needs no adversary proceeding under $\$ 549(\mathrm{a})$. Rather, the trustee can effectuate a turnover under $\$ 542$ (a) if the dollars can be traced. If not, the trustee can sue for the tort of conversion and recover this in personam claim under $\$ 542$ (b).

Second, it should be clear that since $A$ has violated the automatic stay, sanctions are appropriate. What those sanctions might be would bring the present endeavor too far off course. On sanctions awardable for stay violations, see D. Casey Kobi, Note, Staying True to Purpose: Including Corporate Debtors Under Section 362( $h)$ of the Federal Bankruptcy Code, 76 IND. L.J. 243 (2001); David Swarthout, Note, When Is an Individual a Corporation?-When the Court Misinterprets a Statute, That's When, 8 AM. BANKR. INST. L. REV. 151 (2000). The remedy, however, does not include forfeiture of A's security interest in the proceeds themselves. This was the holding of Fleet National Bank v. Gray (In re Bankvest Capital Corp.), Nos. 02-40100 \& 0240101, 2003 U.S. Dist. LEXIS 4876 (D. Mass. March 28, 2003), a case of special interest to the current article for reasons beyond its holding on forfeitures. See infra text accompanying notes 152-58. For the present, however, this case can be read as involving an Article 9 secured creditor that applied postpetition cash proceeds to a prepetition secured claim in violation of 


\section{Subrogation}

Even if, per Lusardi, the $\S 549$ (c) defense has been consigned to the memory hole, courts following that opinion should be sensitive to the separate concept of subrogation. Suppose $A$ purports to sell to $X$ in violation of the automatic stay and, per Lusardi, the $\S 549$ (c) defense does not apply. $X$ might nevertheless be subrogated to $A$ 's valid prepetition security interest. It should always be true that, even if $X$ has bought nothing from the bankruptcy estate, $X$ has, at least, bought A's senior position under ordinary principles of subrogation. ${ }^{127}$ Nothing in the automatic stay prevents $A$ from selling her claim to $X{ }^{128}$

This point was missed in Lusardi where $D$, a bad faith filer, won a judgment of clean title against $X$. Subrogation would have mitigated this result. Although $X$ could not qualify for a $\S 549$ (c) defense because $A$ refused to tender a deed after the auction, the court might have held that $X$ was subrogee to the county's lien on $D$ 's property. As it was, $D$ not only had the advantage of the automatic stay in spite of a bad faith filing, but $D$ was able to foist a tax liability over to $X$ in addition. The fruit of $D$ 's bad faith was therefore a fresher start than good faith debtors get. ${ }^{129}$

Subrogation was likewise overlooked in Burns $v$. Shelton (In re Shelton), ${ }^{130}$ a chapter 7 case in which $A$ obtained relief from the stay.

the automatic stay. The Bankvest court reversed what it took to be a forfeiture order, but, in remanding, it held open the possibility of other sanctions.

The trustee may wish to argue that $A$ 's sale to $X$ destroyed valuable debtor equity where $X$ did not pay full value. But many courts insist that $X$ 's defense depends on $X$ paying the full fair value. See supra notes 111-122. Where such a view is followed, the trustee's dilemma never arises.

27 Roslyn Sav. Bank v. Comcoach Corp. (In re Comcoach Corp.), 698 F.2d 571, 574 (1983). This is the standard state law solution to the circumstance in which $A$ has failed to join a necessary party in a foreclosure proceeding and has nevertheless sold to $X$. $X$ buys $A$ 's position and must redo the foreclosure properly, joining the previously excluded necessary party. Pease Co. v. Huntington Nat'l Bank, 495 N.E.2d 45 (1985). But see In re Ward, 837 F.2d 124 (3d Cir. 1988).

${ }^{128}$ On the postpetition market for secured claims, see Chaim J. Fortgang \& Thomas Moers Mayer, Trading Claims and Taking Control of Corporations in Chapter 11, 12 CARDOzo L. REV. 1 (1990).

129 It appears, however, that $X$ is entitled to a refund from the county holding the illegal foreclosure sale. See CAL. Rev. \& TAX. CODE $§ 3729$ (2001). Presumably, upon refunding the tax, the county would have a lien on $D$ 's property again. If so, then perhaps $D$ will not ultimately escape its proper tax obligation.

130273 B.R. 116 (Bankr. W.D. Ky. 2002), rev'd sub nom Peoples Bank \& Trust Co. v. Burns, 2004 U.S. App. LEXIS 7553 (6th Cir. Apr. 16, 2004). 
Lifting the stay permitted $A$ to foreclose, but it did not mean that the bankruptcy trustee had abandoned debtor equity. The equity was still property of the estate, and $D$ had no power over it. Nevertheless, without authority, $D$ made a quitclaim deed to $X_{1}$ who granted a mortgage on the same land to $X_{2}$. $X_{1}$ used the proceeds from $X_{2}$ 's loan to pay $A$.

This seems to have been a proper case for subrogation. In effect, $X_{1}$ and $X_{2}$ "bought" $A$ 's senior lien. The Shelton court did not see it this way. Rather, it ruled that the bankruptcy estate could have the property free and clear of $X_{1}$ and $X_{2}{ }^{131}$ First, it wrongly viewed the case to be a $\S 549$ (a) avoidance case ${ }^{232}$ instead of a case in which $D$ failed to convey property he had no right to convey. Second, the court viewed $X_{2}$ 's attempted defense as one under $\S 550(\mathrm{e}){ }^{133}$ Section 550 (e) allows for a lien on property for the value of "improvements" if the trustee seeks to recover under $\S 550$ (a). The court ruled that if the trustee could avoid the conveyance to $X_{1}$ under $\S 549$ (a), such a lien was preserved for the benefit of the bankruptcy estate under $\S 551 .^{134}$ Section $550(\mathrm{e})$ cannot serve as a defense to $\S 551 .{ }^{135}$ For this reason, the trustee's $\S 549$ (a) action was vindicated, though in truth $\S 549$ (a) was irrelevant to the matter. Regardless of $\S 550$ (e), however, $X_{1}$ and $X_{2}$ should have prevailed on a theory of subrogation. ${ }^{136}$ The trustee should have title to the property subject to the superior lien of $X_{I}$ and $X_{2}$.

Subrogation is a basic part of the common law of payment. As such, it has nothing to do with the $\S 549$ (c) defense. Accordingly,

$131 \quad$ Id. at 123 .

$132 \quad I d$. at 118 .

133 Id. at 121 .

134 Id.

135 Accord Suhar v. Burns (In re Burns), 322 F.3d 421 (6th Cir. 2003).

136 In Shelton, $X_{2}$ claimed an earmarking defense. The court was justifiably mystified by this claim, because earmarking is a voidable preference term. In re Shelton, 273 B.R. at 122-23. In earmarking, $D$ borrows from $C_{2}$, an unsecured creditor, to pay $C_{1}$, also an unsecured creditor. $D$ is bankrupt soon thereafter. See generally David Gray Carlson \& William H. Widen, The Earmarking Defense to Voidable Preference Liability: A Reconceptualization, 72 AM. BANKR. L.J. 591 (1999) (recharacterizing earmarking as the $\$ 547$ (c)(1) defense in disguise). It is sometimes said that $C$, has not received a preference because the dollars received were $C_{2}$ 's property. It appears, then, that "earmarking" was an inelegant attempt to assert a subrogation theory, which the Shelton court might well have honored in order to prevent unjust enrichment of the bankruptcy estate. On appeal, the Sixth Circuit reversed and remanded for a determination of whether the estate was diminished by $X_{l}$ 's payment. Presumably, on the next try, the bankruptcy court will see the merits of the subrogation theory. 
subrogation should always be available to aid the purchaser of personal property at a lien foreclosure sale. ${ }^{137}$

\section{Dismissals of the Bankmuptcy Proceeding}

Subrogation also helps mitigate the situation when, as in Lusardi, the bankruptcy proceeding engendering the automatic stay is dismissed for bad faith. Suppose Lusardi is rejected as bad law, so that the trustee must always avoid postpetition transfers under $\S 549$ (a), if she can. Dismissal, whether for bad faith or by $D$ 's choice, is governed by Bankruptcy Code $\S 349$ (b), which states:

(b) Unless the court, for cause, orders otherwise, a dismissal of a case other than under section 742 of this title-

(1) reinstates

(B) any transfer avoided under section . . 549 ... of this title; and

(2) vacates any order, judgment, or transfer ordered under section . . 550 ... of this title; and

(3) revests the property of the estate in the entity in which such property was vested immediately before the commencement of the case under this title.

Notice that conveyances "avoided" under $\S 549$ are revived. Under Lusardi, however, conveyances are void for violating the automatic stay and therefore are not resuscitated. Accordingly, courts hold that "void" conveyances stay void, even after a bad faith dismissal. ${ }^{138}$

It is important to note that, if $X$ is $A$ 's subrogee, $X$ can always return to the bankruptcy court, reopen the bankruptcy case, and obtain retrospective annulment of the automatic stay, thereby

${ }^{197}$ For a case ruling out subrogation (which the above-mentioned defense closely resembles) in a strong-arm situation where a loan from an unperfected secured party retired a perfected security interest, see Farmer v. LaSalle Bank (In re Morgan), 291 B.R. 795 (Bankr. E.D. Tenn. 2003). Some courts have ruled that $\S 547$ overrules any concept of subrogation. See, e.g., Boyd v. Superior Bank FSB (In re Lewis), 270 B.R. 215 (Bankr. W.D. Mich. 2001); Sheehan v. Valley Nat'l Bank (In re Shreves), 272 B.R. 614, 621 (Bankr. N.D. W. Va. 2001). But see Hardesty v. Equity One Credit Corp. (In re Farrell), 269 B.R. 181, 187-88 (Bankr. S.D. Ohio 2001) (alternative holding stating unperfected mortgagee had $\S 550(\mathrm{e})(1)$ defense for funds paid to prior perfected mortgagee).

${ }^{138}$ In re D'Alfonso, 211 B.R. 508, 513 (Bankr. E.D. Pa. 1997). 
reviving the entire foreclosure sale. ${ }^{139}$ Even voidness theory admits that a supposedly "void" conveyance can be cured. ${ }^{140}$

Retroactive relief from the automatic stay is sometimes granted just to vindicate the rights of a bona fide purchaser. ${ }^{141}$ But courts wedded to the Lusardi position have begun to insist that retroactive relief to undercut the Lusardi premise is per se illegitimate. One such holding can be found in Fjeldsted $v$. Lien (In re Fjeldsted). ${ }^{142}$ Yet Fjeldsted involved a good faith chapter 13 case that was never dismissed. Where, however, a bankruptcy proceeding has already been dismissed on grounds of bad faith, it is presumptively monstrous not to annul the automatic stay to vindicate the rights of a good faith ${ }^{143}$ purchaser. $^{144}$

\section{B. The Meaning of $\S 542(c)$}

As we have seen, where $\S 542$ (c) applies, $A$ validly conveys free and clear of the automatic stay. Of course, Lusardi overrules this

139 See Jones v. Garcia (In re Jones), 63 F.3d 411 (5th Cir. 1995); Albany Partners, Ltd. v. Westbrook (In re Westbrook), 749 F.2d 670 (11th Cir. 1984); In re Dupuy, 308 B.R. 843 (Bankr. E.D. Tenn. 2004); In re Batton, 308 B.R. 406 (Bankr. W.D. Mo. 2004) (auction held fifteen minutes after bankruptcy petition); Litzler v. CitiCapital Comm. Corp. (In re TIC United Corp.), 304 B.R. 270 (Bankr. N.D. Tex. 2003); In re Lampkin, 116 B.R. 450 (Bankr. D. Md. 1990).

140 In re Soares, 107 F.3d 969, 976 (1st Cir. 1997).

141 See In re Jones, 63 F.3d 411; Little v. Bago (In re Bago), 149 B.R. 610 (Bankr. C.D. Cal. 1993); New Orleans Airport Motel Assocs., Ltd. v. Lee (In re Servico, Inc.), 144 B.R. 933 (Bankr. S.D. Fla 1992).

${ }_{142} 293$ B.R. 12 (B.A.P. 9th Cir. 2003); see also In re Soares, 107 F.3d at 969 (finding knowing violations can never be retroactively cured).

143 What if $X$ deliberately violated the automatic stay by purchasing at $A$ 's foreclosure sale, and $D$ later voluntarily dismissed the proceeding? These were the facts in Sports $\mathcal{E}^{\circ}$ Science, Ind., Inc. v. Rielly (In re Sports E् Science, Ind., Inc.), 95 B.R. 745 (Bankr. C.D. Cal. 1989). Should $X$ receive the benefit of the dismissal when the case is dismissed? The Sports Ev Science court still insisted on absolute voidness. Id. at 747. Yet if the first bankruptcy proceeding was so illegitimate as to warrant dismissal, it seems to the author that the equities sometimes lie with X-not with D. See In re Allen, 300 B.R. 105, 120 (Bankr. D.D.C. 2003) (stay annulled where $A$ and $X$ had no knowledge of the bankruptcy and where $D$ 's bankruptcy petition was filed in bad faith); In re Webb, 294 B.R. 850 (Bankr. E.D. Ark. 2003) (knowing violation in light of a repetitive filer).

${ }^{144}$ This option may still be viable in the Lusardi case. According to the Ninth Circuit, "Lusardi asked the [bankruptcy] court to apply the [bad faith] dismissal retroactively so as to give effect to the tax sale. The parties disagree as to whether the bankruptcy court denied the motion or rather declined to address it. In either case, Lusardi does not now seek relief on the theory that the stay should be retroactively avoided." 40235 Wash. St. Corp. v. Lusardi, 329 F.3d 1076, 1080 n.2 (9th Cir. 2003). 


\section{notion because no cross-reference to $\S 542$ (c) appears in $\$ 362$ (b) to negate automatic stay voidness. ${ }^{145}$ However, assuming that}

145 The Sixth Circuit has arguably ruled that the automatic stay preempts the $\$ 542$ (c) defense. Smith v. First Am. Bank, N.A. (In re Smith), 876 F.2d 524 (6th Cir. 1989), aff'g Smith v. First Am. Bank-Mich., N.A. (In re Smith), 86 B.R. 92 (W.D. Mich. 1988). In this case, prior to the bankruptcy petition, $A$, a secured creditor, repossessed a car. In re Smith, 86 B.R. at $92-$ 93. Without knowledge of the bankruptcy, $A$ sold the car. Id. at 93 . The bankruptcy court held that $A$ had the $\S 542$ (a) defense. Id. The district court disagreed. Id. at 95-96. In a rather confusing opinion, it thought it essential to distinguish another case, In re Smith Corset Shops, Inc., 696 F.2d 971 (1st Cir. 1982). In Smith Corset, A was D's landlord. Id. at 973. In ignorance of a bankruptcy petition, $A$ had the constable evict $D$. Id. The constable put $D$ 's inventory into storage. Id. $D$ sued $A$ for converting girdles to his own use. Id. $A$ offered to tender the girdles back to $A$ but insisted that the conversion action be dismissed. Id. The First Circuit Court of Appeals ruled that no act of conversion occurred. Id. at 977 . In so doing, it referred to $\S 542(\mathrm{c})$ : “ $[D]$ argues that section $542(\mathrm{c})$ does not apply here because it covers only cases in which property is 'transferred' to a third party ... . But whether or not section 542 (c) is technically applicable, it is a powerful indication of congressional acceptance of the principle set out in Bank of Marin." Id. at 976-77 (footnotes omitted). The court went on to point out that $D$ could have notified $A$ of the bankruptcy petition but did not until after the inventory was in the warehouse. Id. at 977 . Notice that the case was not, strictly speaking, a $\S 542$ (c) case, but it did find in $\S 542$ (c) a policy of forgiving offenses to the automatic stay if $A$ is ignorant of the bankruptcy petition.

Back in the Sixth Circuit, the district court thought that the facts in Smith were less egregious than in Smith Corset. Mysteriously, on the subject of $\S 542$ (c), the court remarked:

[A] also argues that the bankruptcy court's ruling is consistent with Smith Corset in light of the specific language of 11 U.S.C. $\$ 542$ (c) which protects the transfer of property of the debtor by an entity that has neither actual notice nor actual knowledge of the commencement of the Chapter 13 case. The Court, however, does not believe that the facts of this case warrant the overriding of the "automatic" provisions of the so-called automatic stay ....

... The Court finds that, in any event, section 542 (c) clearly should not be read to protect postpetition transferees of estate property since section 542(c) protects, at most, only those parties holding property at the time of the petition.

86 B.R. at 95-96, $95 \mathrm{n} .1$. This remark is odd. In Smith, $A$ did have the car in its possession at the start of the case. In re Smith, 86 B.R. at 93 . Furthermore, nothing in $\S 542$ (c) states that its principle is limited to cases in which repossession antedates the bankruptcy petition. All that $\S 542$ (c) requires is a conveyance by $A$ in ignorance of the bankruptcy petition. Nevertheless, the district court ruled that it (not the bankruptcy court) had discretion to ignore $§ 542$ (c) and enforce the automatic stay:

[T] he Court believes that to affirm the bankruptcy court's holding in this case under these facts, would be to take a precarious first step down a slippery slope leading towards the requiring of some sort of formal service of process and/or actual notice of the automatic stay. The Court is well aware of the equitable exception set forth in Smith Corset. However, to apply Smith Corset under these facts would result in suffocating the stay's intended policy of providing some "breathing space" for the debtor and would allow an ad hoc equitable exception to swallow a well-established legal rule.

Id. at 96. In other words, the district court viewed Smith Corset as an equitable case (which it was), and viewed $\S 542$ (c) as something it could ignore in the name of equity. Finally, and extraordinarily, the district court compelled $A$ to return the proceeds and permitted $D$ to buy 
Lusardi's negation of Bankruptcy Code provisions in the name of equity is illegitimate, it has not been recognized that if $A$ validly conveys, $X$ validly receives the property free and clear of the automatic stay. A cannot transfer property of the bankruptcy estate unless there is a transferee. Only in California can one enfeoff oneself. $^{146}$ Thus, $\S 542$ (c) expressly promises that $A$ 's transfer has the same effect as if the transfer has been made prepetition. According to $\S 542$ (c), if $A$ has no notice or knowledge of the bankruptcy petition, $A$ "may transfer property of the estate, or pay a debt owing to the debtor ... to an entity other than the trustee, with the same effect as to the entity making such transfer or payment as if the case under this title concerning the debtor had not been commenced." ${ }^{, 147}$ The grammar of this sentence is somewhat confusing. But it essentially says that $A$ makes an effective transfer if $A$ is ignorant of the bankruptcy. Surely this section must be read in conjunction with $\S 362$ (a) so that $\S 542$ (c) is an implicit exception to the automatic stay. How can $\S 362$ (a) prohibit what $\S 542$ (c) invites?

On the other hand, under $\S 549(\mathrm{a})$-assuming no defense applies-the trustee can avoid the transfer "(A) that is authorized only under section 303 (f) or 542(c) of this title; or (B) that is not authorized under this title or by the court." Indeed, the very reference to $\S 542$ (c) in $\S 549$ (a) (2) (A) proves that the conveyance to $X$ is valid but for avoidance under $\S 549$ (a).

\section{Conveyances by Involuntary Bankrupts}

Suppose, in lieu of greatness, $D$ has bankruptcy thrust upon him. Prior to the actual adjudication, $D$, under Bankruptcy Code $\S 303$ (f), may "dispose of property as if an involuntary case concerning the debtor had not been commenced." The trustee may still be able to avoid the transfer under $\$ 549(\mathrm{a})$ because $\S 549$ (a) (2) (A) permits avoidance of transfers "authorized only

\footnotetext{
a new car with them, granting $A$ a new security interest for the forced loan. Id. at 98.

The Sixth Circuit Court of Appeals affirmed, In re Smith, 876 F.2d at 527, but said nothing about $\S 542$ (c). It too concentrated on distinguishing Smith Corset. Id. at 525-26. So has the Sixth Circuit ruled that the automatic stay trumps $§ 542$ (c)? Possibly so, though the matter is confused.

${ }^{146}$ Riddle v. Harmon, 162 Cal. Rptr. 530, 531 (1980) ("We discard the archaic rule that one cannot enfeoff oneself ....").

${ }_{147} 11$ U.S.C. $\$ 542(c)(2000)$.
} 
under section $303(\mathrm{f})$ or $542(\mathrm{c})$ of this title." Section $549(\mathrm{~b})$, however, provides a defense, provided the transfer was not a satisfaction or securing of an antecedent debt. ${ }^{148}$

Significantly, courts rarely contend that acts pursuant to $\S 303$ (f) violate the automatic stay. ${ }^{149}$ More commonly, courts rule that "gap period transactions are avoidable only under sections 549(a)(2)(A) and 549(b); the court cannot avoid this restriction simply by ignoring the gap period." ${ }^{150}$ It seems, then, that $\S 303$ (f) constitutes a defense from automatic stay voidness for both $D$ and $X^{151}$

Now, if this is true for $\S 303$ (f), it is likewise true for $\S 542$ (c). When either $\S 303(\mathrm{f})$ or $\S 542$ (c) empowers a person to convey property of the bankruptcy estate, there can be no question of voidness under the automatic stay. The transferee validly receives property, which the trustee must avoid, if she can, under $\S 549$ (a).

One recent dissent with regard to $\S 303$ (f) is Fleet National Bank v. Gray (In re Bankvest Capital Corp). ${ }^{152}$ In Bankvest, $D$ borrowed from $A$ to buy equipment for lease to customers. Upon leasing the equipment, $D$ would sell its reversionary interests and use the proceeds to repay $A$. $D$ was forced involuntarily into bankruptcy,

${ }_{148}$ See Cossitt v. First Am. State Bank (In re Fort Dodge Creamery, Inc.), 121 B.R. 831, 836 (Bankr. N.D. Iowa 1990) (holding voluntary payment of antecedent debt voidable under $\S 549(\mathrm{a}))$. "Present transfer" has been loosely interpreted. For instance, where a debtor owes rent at the beginning of the month and pays seven days into the month, the entire rent payment is "present" consideration, and none of it satisfies an antecedent debt. Guinn v. Oakwood Props., Inc. (In re Oakwood Mkts., Inc.), 203 F.3d 406 (6th Cir. 2000). Advance payment has also been upheld. Yancey v. Varner (In re Pucci Shoes, Inc.), 120 F.3d 38 (4th Cir. 1997).

149 Official Comm. of Creditors v. Union Bank (In re Tex. Research, Inc.), 862 F.2d 1161 (5th Cir. 1989) (upholding gap security interest with no mention of automatic stay violation).

${ }^{150}$ Hamilton v. Lumsden (In re Geothermal Res. Int'l, Inc.), 93 F.3d 648, 651 (9th Cir. 1996) (holding executory contracts in the gap period can be upheld if reasonably equivalent values exist).

${ }^{151}$ See Joseph Mullin, Note, Bridging the Gap: Defining the Debtor's Status During the Involuntary Gap Period, 61 U. CHI. L. REV. 1091, 1109 (1994). One court may have gone too far in ruling that the automatic stay never applies in the gap. In re Acelor, 169 B.R. 764, 765 (Bankr. S.D. Fla. 1994) ("It can not be presumed that the intent of Congress was to provide that all acts of creditors are totally stayed upon the filing of an involuntary petition whilst the debtor is free to wander the financial meadows without any controls or inhibitions as to its acts or omissions."). The argument here is only that where $D$ exercises her $\S 303$ (f) power, the automatic stay does not prevent a transferee from receiving the transfer. See Mann v. Marine Bank W. (In re Omni Graphics, Inc.), 119 B.R. 641 (Bankr. E.D. Wis. 1990) (holding where $A$ repossessed before petition and held a foreclosure sale in the gap, $A$ violated the automatic stay).

${ }^{152} 375$ F.3d 51 (1st Cir. 2004), rev'g 276 B.R. 12 (Bankr. D. Mass. 2002). 
and $A$ nevertheless received some proceeds from $D$ on its antecedent debt during the gap period. Although the trustee ${ }^{153}$ brought an action under $\S 549(\mathrm{a})$, the bankruptcy court insisted, contrary to what I have said, that $A$ also violated the automatic stay by receiving what $D$ voluntarily gave. ${ }^{154}$ This holding was more or less confirmed on appeal. ${ }^{155}$ Underlying Bankvest is the premise that all conveyances authorized under $\S 303(\mathrm{f})$ are void as violations of the automatic stay. ${ }^{156}$

Although Bankvest can be read as erasing $\S 303(\mathrm{f})$ by means of automatic stay voidness, the trustee won no victory after all. Although $A$ had no defense under $\S 549$ (b) because it received funds on antecedent debt, it nevertheless had a valid security interest on the funds it received. Once these proceeds were recovered, the trustee had to honor $A$ 's secured claim, which was resuscitated under $\S 502(\mathrm{~h}) .^{157}$ In effect, the trustee's theory was worthless. ${ }^{158}$

\footnotetext{
153 More precisely, a post-confirmation liquidating trustee.

154 In re Bankvest Captal Corp., 276 B.R. at 25-27.

155 A subsequent court, however, has ruled,
}

[t] he matter of the stay violation was not at issue in [the Bankvest] appeal. In a footnote, the court stated that they were proceeding "in this opinion on the assumption, also held by the bankruptcy and district courts, that a violation occurred and that the ... avoidance of Fleet's receipt of those payments was in order except for reasons otherwise discussed herein." In a later footnote, the court again referred to the automatic stay and explained that "Fleet has provided no coherent grounds for us to conclude that its retention of the gap payments was permissible and therefore that avoidance would be improper. Accordingly, we shall assume that the decisions below were correct insofar as they found that the avoidance would otherwise be in order ...."

In re Gaudreault, 315 B.R. 1, 7 (Bankr. D. Mass. 2004) (citations omitted). Given the presuppositional nature of the First Circuit opinion, the Gaudreault court felt free to hold that $\S 303$ (f) overrules automatic stay voidness.

${ }^{156}$ Similarly, in In re E.D. Wilkins Grain Co., 235 B.R. 647 (Bankr. E.D. Cal. 1999), A was a secured creditor claiming accounts receivable. $D$ and $A$ stipulated that the automatic stay should be lifted to allow $D$ to draw down loans from $A$ and remit proceeds to $A$. Id. at 649 . The court refused to approve this stipulation and instead insisted that $A$ move to lift the stay after serving papers on the United States attorney and the petitioning creditors. Id. Based on what the author has suggested, however, the automatic stay did not apply at all, so long as $D$ 's actions constituted "operating a business" within the meaning of $\S 303(\mathrm{f})$.

${ }^{157}$ Bankvest, 375 F.3d at $66-70$. According to $\$ 502(\mathrm{~h})$, “[a] claim arising from the recovery of property under section . . $550 \ldots$ shall be determined, and shall be allowed ... or disallowed ... the same as if such claim had arisen before the date of the filing of the petition."

${ }^{158}$ Why then did the liquidation trustee bring the action? There was a weird turn in Bankvest. After it received the proceeds and applied them to its secured claim, $A$ sold the remainder of its bankruptcy claim against $D$ to $X$. Bankvest, $375 \mathrm{~F} .3 \mathrm{~d}$ at 56 . The sales 


\section{Statute of Limitations}

Section 549 (d) provides a statute of limitations: "An action or proceeding under this section may not be commenced after the earlier of-(1) two years after the date of the transfer sought to be avoided; or (2) the time the case is closed ...." In the case where $D$ or $A$ has a genuine power to convey property of the estate, the statute of limitations is appropriately applied. For example, in the involuntary "gap" where $D$ conveys property, the conveyance is fully authorized in spite of the automatic stay. It may still be avoided under $\S 549(\mathrm{a})$, however. In such a case, the statute of limitations is properly considered. ${ }^{159}$ But in cases where $\S 549(\mathrm{a})$ is wrongly invoked (because the debtor has no power to convey away the debtor's property), the statute of limitations should never apply. ${ }^{160}$ It therefore becomes a matter of importance to focus on whether the trustee needs an avoidance theory under $\S 549$ (a) or not.

Meanwhile, if automatic stay voidness reigns supreme, $\S 549$ (d) is one of the provisions read out of the Bankruptcy Code. Automatic stay voidness implies that neither $D$ nor $A$ ever conveyed anything to $X$ in the first place. Once again, judge-made law wipes out an express enactment of Congress.

agreement between $A$ and $X$ was very broad indeed, covering all claims by $A$ against the bankruptcy estate, "whether known or unknown." Id. The trustee alleged that the meaning of this agreement was that, when $A$ surrendered the cash proceeds back to the trustee, $X$ (not $A$ ) had the secured claim against the bankruptcy estate. Id. at 63 . Yet $X$ had previously released all claims against $D . I d$. Hence, the trustee reasoned that the trustee could retain the cash proceeds free and clear of A's security interest. Id. The bankruptcy court agreed with the trustee. $I d$.

On appeal, the district court apparently read the bankruptcy court as ordering a forfeiture of the security interest as a penalty for violating the stay. It reversed, holding the penalty of forfeiture did not fit the crime of stay violation. Id. at 65 . In truth, the bankruptcy court seemed to be ruling only that $X$, not $A$, owned the security interest in the proceeds. It was not imposing any penalty on $A$ but determining ownership of the secured claim under the contract between $A$ and $X$.

On further appeal, the First Circuit ruled that the agreement between $A$ and $X$ simply did not cover proceeds $A$ would have to surrender to the trustee. Id. at 66 . Therefore, $A$ had a valid security interest in whatever it surrendered to the trustee. Id. The entire law suit unraveled for the trustee at this point.

${ }_{159}$ Consol. Partners Inv. Co. v. Lake (In re Consol. Partners Inv. Co.), 152 B.R. 485 (Bankr. N.D. Ohio 1993).

${ }_{160}$ See supra text accompanying notes 22-56. 


\section{E. Grace Periods Under State Law}

\section{Postpetition Perfections}

Bankruptcy Code $\S 546$ (b) (1) provides an express defense to $\S 549$ avoidance:

The rights and powers of a trustee under sections 544, 545, and 549 of this title are subject to any generally applicable law that-

(A) permits perfection of an interest in property to be effective against an entity that acquires rights in such property before the date of perfection ....

This provision equally empowers debtors to make conveyances in derogation of the automatic stay. According to $\S 362$ (b) (3), the automatic stay does not prohibit "any act to perfect ... an interest in property to the extent that the trustee's rights and powers are subject to such perfection under section 546(b) of this title ...." In general, any act falling within $\S 546(b)$ is immune both from $\S 549$ (a) avoidance and automatic stay voidness.

In Lusardi, the county refused to issue $X$ a deed in light of the automatic stay. Therefore, $X$ had nothing to record, and $D$ 's eventual recording of the bankruptcy notification doomed $X$ 's attempt to invoke the $\S 549$ (c) defense. But what if $X$ had obtained the deed and recorded it? Might not this act of perfection fall within $\S 546$ (b) (1)? According to this provision: "The rights and powers of a trustee under sections 544,545 , and 549 of this title are subject to any generally applicable law that-(A) permits perfection of an interest in property to be effective against an entity that acquires rights in such property before the date of perfection ...." $X$ 's perfection would appear to fit within $\$ 546(\mathrm{~b})(1)(\mathrm{A})$. The trustee is "an entity that acquires rights in such property before the date of perfection." That is, when $D$ files for bankruptcy, the trustee obtains ownership of $D$ 's equity. Section 549 (c) is part of the "generally applicable law," ${ }^{\text {"161 }}$ and it permits $X$ to defeat an entity who is prior in time. $X$ s s claim to fall within $\$ 546$ (b) (1) would seem to be a good one.

161 Notice that $\$ 541$ (c)(1) refers to "applicable nonbankruptcy law." "Generally applicable law" within the meaning of $\S 546$ (b)(1) must therefore include bankruptcy law as well as state law. 
Value T Sales, Inc. v. Mitchell (In re Mitchell) ${ }^{162}$ held otherwise. It held that the sale from $A$ (who knew of the bankruptcy) to $X$ (who did not) was itself void as violating the automatic stay. This meant $X$ had no interest that could be perfected. ${ }^{163}$ Ironically, if $A$ had been ignorant of the bankruptcy, then $\S 542$ (c) would have applied, presuming Lusardi-style reasoning had not wiped it out. If $\S 542$ (c) applied, $A$ validly conveyed an interest to $X,{ }^{164}$ and $X$ validly perfected it under $\$ 546$ (b) (1) free and clear of the automatic stay and $\S 549$ (a) avoidance. This leaves $X$, a bona fide purchaser, in a very strange position. If $A$ knows of the bankruptcy, $X$ loses under Mitchell. If $A$ does not know, $X$ wins. Surely this is acephalous law indeed, if any doubts on that score still remain.

\section{Postpetition Advances}

An important issue for the current article concerns postpetition advances $A$ makes under a prepetition security agreement with $D$, where $D$ personally (as opposed to the bankruptcy trustee or debtorin-possession) obtains the advances. Sometimes A's advances create a lien that is senior to the lien of the intervening party. For example, under U.C.C. $\$ 9-323($ b), a lender may make senior advances to a prior judicial lien for forty-five days after the lien attaches or any time before the lender has knowledge of the judicial lien. ${ }^{165}$ This is established by the "negative pregnant" of $\S 9-323(\mathrm{~b})$, which provides:

[A] security interest is subordinate to the rights of a person that becomes a lien creditor to the extent that the security interest secures

$162 \quad 279$ B.R. 839 (B.A.P. 9th Cir. 2002).

${ }_{163} I d$. at 844 ("As the foreclosure sale was itself void, later perfection could not validate it."). Furthermore, the court even ruled in a subsequent case that it is an abuse of discretion to annul the automatic stay retroactively just so $X$ can vindicate the $\S 549$ (c) defense by perfecting within the meaning of $\S 546$ (b) (1)(A). Fjeldsted v. Lien (In re Fjeldsted), 293 B.R. 12 (B.A.P. 9th Cir. 2003). Other courts have ruled just the opposite-that access to the $\S 549$ (c) defense is per se grounds to annul the stay. Jones v. Garcia (In re Jones), 63 F.3d 411, 412 (5th Cir. 1995); Little v. Bago (In re Bago), 149 B.R. 610, 614 (Bankr. C.D. Cal. 1993); New Orleans Airport Motel Assocs., Ltd. v. Lee (In re Servico, Inc.), 144 B.R. 933 (Bankr. S.D. Fla. 1992).

${ }^{164}$ Sikes v. Global Marine, Inc., 881 F.2d 176, 179 (5th Cir. 1989).

${ }_{165}$ E.g., UNI Imports, Inc. v. Aparacor, Inc., 978 F.2d 984 (7th Cir. 1992) (noting advances during the forty-five day period were senior, advances with knowledge thereafter were not). 
an advance made more than 45 days after the person becomes a lien creditor unless the advance is made:

(1) without knowledge of the lien; or

(2) pursuant to a commitment entered into without knowledge of the lien. ${ }^{166}$

Under state law, $D$ has the power to create senior security interests for its lenders forty-five days after a judicial lien attaches. ${ }^{167}$

Real estate law likewise empowers $D$, on occasion, to create senior security interests by accepting advances after the intervention of a lien. For example, Missouri law states:

As to any third party who may acquire... a lien upon the encumbered real property, the priority of ... future advances... shall date from the time the security instrument is recorded, whether or not any third party has actual notice of any such advances or obligations and whether or not such advances or obligations are optional or obligatory with the lender ....

Under this provision, $A$ 's post-encumbrance advances to $D$ are senior to prior encumbrances.

Section 546(b) (1) arguably invites $A$ to take a lien senior to the trustee's lien by making postpetition advances to $D$. Perfection, at least under Article 9, means attachment plus some extra step of "publicity." As9 Assuming a prepetition financing statement is properly filed, $D$ 's postpetition advance simultaneously creates and perfects a senior security interest for $A$ (if the advance is made without knowledge or within forty-five days of the bankruptcy).

There is, however, a lively controversy over whether $\S 546$ (b) (1) countenances lien creation as well as lien perfection. Some courts have assumed that postpetition perfection is permitted only if lien creation occurred prepetition. ${ }^{170}$ Yet nothing on the face of $\S 546$ (b) (1) requires such a conclusion. All that $\$ 546$ (b) (1) requires is that (1) an act constitute "perfection" of an interest and

\footnotetext{
166 U.C.C. $\$ 9-323$ (b) (2000).

${ }^{167}$ David Gray Carlson \& Paul M. Shupack, Judicial Lien Priorities Under Article 9 of the Uniform Commercial Code (pt. I), 5 CARDOZO L. REV. 287, 346-68 (1984).

${ }_{168}$ MO. REV. STAT. $\$ 443.055 .5$ (2000).

169 U.C.C. $\$ 9-308(a)$.

170 Lincoln Sav. Bank v. Suffolk County Treasurer (In re Parr Meadows Racing Ass'n), 880 F.2d 1540, 1546-47 (2d Cir. 1989), cert. denied, 493 U.S. 1058 (1990).
} 
(2) seniority of that interest (under state law) to "an entity that acquires rights in such property before the date of perfection." If read literally, $\S 546$ (b) (1) seems to cover the future advance that "perfects" a senior security interest. ${ }^{171}$

In 229 Main Street Ltd. $v$. Massachusetts Department of Environmental Protection (In re 229 Main Street Ltd.), ${ }^{172}$ a bankruptcy trustee argued that, whereas $\S 362$ (a) (4) prohibits any act to create or perfect a lien, $\S 362$ (b) (3) exempts only acts to perfect. ${ }^{173}$ The supposed implication of this observation is that creation is a void act, but perfecting a prepetition lien is permitted. Therefore, only perfection apart from lien creation is permitted. The Main Street court, however, rejected this argument. In Main Street, the state environmental agency "created" and perfected a postpetition lien and was nevertheless protected under $\S 546(\mathrm{~b}) .{ }^{174}$ "Under the debtor's theory," the court remarked, "an act that effected the concurrent creation and perfection of a lien would, at one and the same time, be both stayed (by section 362(a)(4)) and exempted from the stay (by section 362(a) (3)). We decline to indulge in so schizophrenic a reading of the Bankruptcy Code."175 Ultimately, Main Street is ambiguous on the point of postpetition lien creation because it purports to find the state had a prepetition "interest" in the collateral. The prepetition interest was an unsecured claim which might become a lien (but was not yet one). In other words, the prepetition in personam claim was already an inchoate in rem claim. Quite apart from this questionable suggestion, Main Street nevertheless seems to suggest that the simultaneous postpetition creation and perfection of a lien falls within the protection of $\S 546$ (b) (1).

Some courts require that state law demonstrate an overt notion of "relation back" before $\$ 546$ (b) (1) applies. This is typically deduced from the legislative history that gives, as an example, the filing of a U.C.C. financing statement within the grace period for

${ }_{171}$ Makoroff v. City of Lockport, 916 F.2d 890, 892 (3d Cir. 1990) (“Under various sections of the U.C.C., a perfected security interest relates back to either the filing of a financing statement or the date that the security interest attaches.").

$172 \quad 262$ F.3d 1 (1st Cir. 2001).

$173 \quad$ Id. at 9 .

174 Id.

${ }^{175}$ Id.; see also Klein v. Civale \& Trovato, Inc. (In re Lionel Corp.), 29 F.3d 88 (2d Cir. 1994) (holding an act to enforce which was also act to perfect was protected under $\S \S 362$ (b) (3) and 546(b) (1)). 
purchase money security interests. ${ }^{176}$ In such an example, $A$ has an unperfected security interest before bankruptcy and perfection after bankruptcy. Thus, in In re AR Accessories Group, Inc., ${ }^{177}$ a state agency obtained a postpetition superpriority lien for unpaid wages when it filed a notice. The $A R$ court did not require the state statute to have an overt relation back feature on its face. ${ }^{178}$ Nevertheless, it required a prepetition unsecured claim for wages to which the superpriority could "relate back." 179

According to at least some courts, then, the issue with discretionary advances is whether the new lien relates back to some prepetition event. This question implicates us in a famous tussle over the status of new advances between Peter Coogan ${ }^{180}$ and Grant Gilmore, ${ }^{181}$ at the dawn of Article 9 jurisprudence. Gilmore proffered a "unitary" theory of the security interest. ${ }^{182}$ Suppose $D$ grants $A$ a prepetition security interest in a thing. $D$ then files for bankruptcy. $A$ then makes a discretionary advance to $D$ in derogation of the bankruptcy estate. Gilmore would have said that the security interest in question "relates back." That is, the security interest is purely prepetition even though a quantitative component of the lien is postpetition. This view privileges the qualitative moment of the lien-the power of sale-over the quantitative moment. The power of sale in $A$ is fully set before the bankruptcy petition. The future advance does not alter the power of sale, only the quantity of cash $A$ can retain once the power of sale is exercised. Such a view of the discretionary advance entails a clear "relation back" element. In contrast, Coogan emphasized a multiple theory of security interests. ${ }^{183}$ In the Coogan view, $A$ has two security interests: one perfected prepetition and one perfected postpetition. ${ }^{184}$

${ }^{176}$ Makoroff, 916 F.2d at 892, 892 n.1 (3d Cir. 1990) (citing H.R. REP. No. 95-595, at 371$72(1977))$. The grace period is currently found in U.C.C. $\$ 9-317$ (2000).

${ }^{177} 345$ F.3d 454 (7th Cir. 2003).

$178 I d$. at 458 ("[W]e hold that a priming statute need not contain language expressly providing for retroactive perfection in order to trigger the exception provided in 11 U.S.C. $\S 546$ (b) (1) (A) ....").

179 Id.

180 Peter F. Coogan, Article 9 of the Uniform Commercial Code: Priorities Among Secured Creditors and the "Floating Lien," 72 HARV. L. REV. 838, 868 (1959).

1812 GRANT Gilmore, SeCURITY INTERESTS In PERSONAL PROPERTY $§ 35.6$, at 935 (1965).

182 See id.

183 Coogan, supra note 180 , at $873-80$.

${ }^{184}$ See id. 
Coogan won the day, and his view lives registered in the 1972 amendments to the U.C.C., which indicate that, at least some of the time, the discretionary advance creates a junior security interest. ${ }^{185}$ Some of the time, however, it creates a senior security interest. ${ }^{186}$ Under the multiple theory, is there a "relation back"? It is possible to see the new advance as part of the prepetition lien, in which case a "relation back" is achieved. It is also possible to view the new advance as creating an entirely separate lien, which does not "relate back." Meanwhile, it is not even clear that $\$ 546$ (b) (1) requires a "relation back" theory in order to function. ${ }^{187}$

In the end, however, $§ 546$ (b) may not apply in discretionary advance cases, but for a rather indirect reason. Bankruptcy effectively destroys loan facilities calling for advances, so that any postpetition advance is simply not within the purview of the agreement anymore. Rather, the future advance is simply an unsecured advance. This is so because the power of $D$ to draw funds from $A$ is part of an executory contract governed by Bankruptcy Code $\S 365$. Such a loan facility, however, is a financial accommodation contract within the meaning of $\S 365$ (c) (2).$^{188}$ At least one court has held that it is impossible for a bankruptcy trustee ever to assume such a contract, even if the creditor consents. ${ }^{189}$ Section 365(c) (2) suggests that the trustee can never compel $A$ to make advances to the bankruptcy trustee by assuming the security agreement between $A$ and $D$. But how does $\S 365$ (c)(2) affect advances to $D$ (not to the trustee)?

The proper answer is that the executory contract is itself property of the bankruptcy estate. In effect, when $D$ files for

185 U.C.C. $\$ 9-301$ (4) (1978).

${ }^{186}$ See generally Jeanne L. Schroeder \& David Gray Carlson, Future Nomadvance Obligations Under Article 9 of the UCC: Legitimate Priority or Unwarranted Squeeze-Out?, 102 BANKING L.J. 412 (1985) (reviewing this debate).

${ }^{187}$ A similar issue exists for fraudulent transfer law. Where $D$ has guaranteed discretionary advances to $S$, each new advance is deemed to be a new fraudulent transfer for statute of limitations purposes. Rubin v. Mfrs. Hanover Trust Co., 661 F.2d 979, 990 (2d Cir. 1981); Steven L. Schwarcz, The Impact of Fraudulent Conveyance Law on Future Advances Supported by Upstream Guaranties and Security Interests, 9 CARDOzo L. REv. 729 (1987).

${ }_{188}$ Section 365 (c) (2) provides: "The trustee may not assume or assign any executory contract or unexpired lease of the debtor ... if ... (2) such contract is a contract to make a loan, or extend other debt financing or financial accommodations, to or for the benefit of the debtor...."

189 Transamerica Commercial Fin. Corp. v. Citibank, N.A. (In re Sun Runner Marine, Inc.), 945 F.2d 1089 (9th Cir. 1991). 
bankruptcy, $D$ conveys all executory contracts to the bankruptcy estate. In the case of the security agreement permitting senior secured advances, $D$ surrenders the right to draw on $A$ to the bankruptcy trustee. This right against $A$ is an asset of the bankruptcy estate. ${ }^{190}$ The trustee, however, is compelled by $\S 365$ (c) (2) to reject this right to draw. Upon rejection, which happens instantaneously and inexorably, the right to draw-a right against $A$-is in effect tendered back to $A$. In different words, the bankruptcy trustee releases $A$ from $A$ 's obligation to advance funds. This right to draw does not revert back to $D$. Therefore, if $A$ does advance funds to $D$, the advance is not under the security agreement. Because the advance is not covered by the security agreement, it cannot encumber estate property. This, I maintain, best explains why postpetition advances are not privileged under $\$ 546$ (b) (1) to create senior liens on the bankruptcy estate. ${ }^{191}$ This point will become significant for my analysis of the important case

190 See David Gray Carlson \& William H. Widen, Letters of Credit, Voidable Preferences, and the "Independence" Principle, 54 BUS. LAW. 1661, 1675-76 (1999).

191 Not all postpetition value extended by $A$ will be in the form of advances, in which case $\S 546$ (b) might apply after all. In Snyder v. Dewoskin (In re Mahendra), 131 F.3d 750 (8th Cir. 1997), $A$ was an attorney who gave bankruptcy advice to $D$. $A$ held a mortgage on $D$ 's house for postpetition services rendered. Id. at 753. The court implied that if $A$ 's postpetition "advances" were senior to third parties under Missouri law, it would be senior to the bankruptcy trustee. Id. at 755. Nevertheless, the court decided against $A$. $I d$. at 756 . It cited Missouri Revised Statutes $\S 443.055 .6$, which permits an adversely affected party to serve notice on $A$ by registered mail that it considered $A$ 's future advance power to be canceled. $I d$. at 755 . If such notice was sent, then $A$ had to file notice of its outstanding secured claim and could make no further claims beyond the amount recorded.

The Mahendra court ruled, very dubiously, that $A$ 's knowledge of the bankruptcy petition was the equivalent of the trustee serving a registered letter on $A$. Id. at 759-60. In other words, bankruptcy trustees have a per se defense against $A$ as a matter of Missouri law. See id. This solution-which probably must be accounted as a gross butchery of Missouri law-invites Missouri to legislate a different result in derogation of a bankruptcy trustee's rights.

Whatever one thinks of the Mahendra court's interpretation of Missouri law, there is much else shocking in the Mahendra opinion which is beyond the scope of this article. For example, $D$ was allowed to assert exemption rights against $A$ 's mortgage for postpetition interest. Id. at 750. This could not be more wrong. Indeed, such a holding suggests that $D$ 's exemption is just as good against any prepetition mortgage for postpetition interest, or even against prepetition mortgage claims. Furthermore, the court ruled that $A$ could not claim a mortgage on $D$ 's property and represent $D$ in a chapter 7 case because $D$ violated the conflict of interest rules in Bankruptcy Code $\$ 327$ (a). Id. at 757. Yet $\S 327$ (a) applied to counsel for the bankruptcy trustee, never $D$ 's private counsel. Furthermore, $A$ was sanctioned under Rule 11 for his so-called conflict of interest and for making a frivolous appeal. Id. at 759-60. Clearly the Mahendra opinion must be viewed as acephalous. In most of the above respects it should be ignored as uncommonly bad law. 
of Beeler v. Jewell (In re Stanton), ${ }^{192}$ which involved postpetition advances under $D$ 's prepetition security agreement. ${ }^{193}$

\section{F. Postpetition Ad Valorem Taxes}

Another implied defense against $\S 549$ (a) avoidance is the postpetition creation of ad valorem property tax liens. Prior to 1994, a lively controversy brewed over the status of property tax liens which arose postpetition as a matter of state law. Some courts thought that, qualitatively, these liens were latent prepetition liens whose quantitative nature might expand postpetition without violating the automatic stay. ${ }^{194}$ Other courts proclaimed the liens void $^{195}$ or voidable ${ }^{196}$ as violating the automatic stay. It was equally true that these liens were avoidable under $\$ 549(\mathrm{a}) .^{197}$

In 1994, Congress attempted to aid local taxing authorities by enacting $\S 362$ (b) (18), which permits "the creation or perfection of a statutory lien for [] ad valorem property tax [es] ... if such tax comes due after the filing of the petition." This prevents voidness on an automatic stay theory but does nothing to prevent $\S 549$ (a) avoidance.

I am tempted to suggest that $\S 362$ (b)(18) is an implied defense to $\S 549$ (a) avoidance; Congress could not have intended to permit the attachment of liens, insofar as the automatic stay was concerned, while reserving for the trustee the right to avoid them under $\S 549(\mathrm{a})$. In any case, the trustee has a better theory than $\S 549$ (a). The very liens preserved by Congress in 1994 are subordinate under the provisions of Bankruptcy Code $\S 724$ (b) to administrative and other high-priority claims. According to $\S 724(\mathrm{~b})$ :

192303 F.3d 939 (9th Cir. 2002), aff'g 248 B.R. 823 (B.A.P. 9th Cir. 2000). An earlier withdrawn opinion exists at 285 F.3d 888 (9th Cir. 2002).

193 See infra text accompanying notes 271-73.

194 Md. Nat'l Bank v. Mayor of Baltimore (In re Md. Glass Co.), 723 F.2d 1138, 1142-43 (4th Cir. 1983).

195 Lincoln Sav. Bank v. Suffolk County Treasurer (In re Parr Meadows Racing Ass'n), 880 F.2d 1540 (2d Cir. 1989), cert. denied, 493 U.S. 1058 (1990).

196 City of Farmers Branch v. Pointer (In re Pointer), 952 F.2d 82 (5th Cir. 1992) (noting lien was voidable but senior secured creditor had no standing to avoid).

${ }^{197} I d$. at $88 \mathrm{n} .8$. 
Property in which the estate has an interest and that is subject to a lien that is not avoidable under this title and that secures an allowed claim for a tax, or proceeds of such property, shall be distributed-

$\cdots$

(2) second, to any holder of a claim of a kind specified in section 507 (a) (1) ... [through] ... Section 507(a) (7) of this title, to the extent of the amount of such allowed tax claim that is secured by such tax lien;

(3) third, to the holder of such tax lien, to any extent that such holder's allowed tax claim that is secured by such tax lien exceeds any amount distributed under paragraph (2) of this subsection;

(4) fourth, to any holder of an allowed claim secured by a lien on such property that is not avoidable under this title and that is junior to such tax lien;

(5) fifth, to the holder of such tax lien, to the extent that such holder's allowed claim secured by such tax lien is not paid under paragraph (3) of this subsection; and

(6) sixth, to the estate.

Even if a property tax lien creditor is saved by $\S 362$ (b) (18) from automatic stay voidness (and presumably from $\S 549$ (a) avoidance), the tax lien may well fail because of the distribution scheme described under $\S 724(\mathrm{~b}) .{ }^{198}$ For example, where $D$ grants $A$ a valid mortgage which is now underwater and where the county claims a superpriority tax lien senior to the lien of $A$, the county obtains no distribution under $\$ 724(\mathrm{~b})(3)$ if the trustee's administrative expenses under $\S 507$ (a) exceed the amount of the property tax. ${ }^{199}$ In spite of the 1984 amendments, then, it is unclear whether the postpetition county tax creditor obtains any benefit from its postpetition lien. ${ }^{200}$

198 Bd. of Supervisors v. King (In re Van Metre, Jr., Inc.), No. 93-1706, 1994 U.S. App. LEXIS 935 (4th Cir. Jan. 20, 1994); Marc Stuart Goldberg, P.C. v. City of N.Y. (In re Navis Realty), 193 B.R. 998 (Bankr. E.D.N.Y. 1996); In re Oglesby, 196 B.R. 938 (Bankr. E.D. Va. 1996).

199 Morgan v. K.C. Mach. \& Tool Co. (In re K.C. Mach. \& Tool Co.), 816 F.2d 238 (6th Cir. 1987). Or even if the administrative expenses are less than the property tax, the other priorities described in $\$ 507(\mathrm{a})(1)-(7)$ must be considered as well. Because $A$ 's claim encompasses the entire value of the real estate after the county's tax lien, the county also obtains no distribution under $§ 724$ (b) (5).

${ }^{200}$ Weirdly, perhaps the county can claim to be an administrative creditor under $\S 507$ (a) (1), and therefore entitled to join in a $\$ 724(\mathrm{~b})(2)$ distribution. Administrative claims are defined by $\S 503(\mathrm{~b})$. Section $503(\mathrm{~b})(1)(\mathrm{B})$ excludes any tax described by $\S 507$ (a) (8), but a property tax assessed postpetition is not described by $\S 507(\mathrm{a})(8)$. 


\section{G. The Defenses in $\$ 550$}

As a final matter, defenses are presented in $\$ 550(\mathrm{a})$. For example, $\$ 550(\mathrm{e})$ gives to $X$ a lien for the amount of any improvement made to property of the estate wrongly retained. The question is whether the defense is available against avoidance actions under $\S 549(\mathrm{a})$.

This question-a most troublesome one-pertains not only to $\S 549$ (a) avoidance, but to fraudulent transfers, voidable preferences, and the like. As the purpose and meaning of the $\S 550$ (a) defenses have been covered more generally elsewhere, ${ }^{201}$ these matters will only be summarized here.

According to $\S 550(\mathrm{a})$ :

[T] o the extent that a transfer is avoided under section ... 549 ... the trustee may recover, for the benefit of the estate, the property transferred, or, if the court so orders, the value of such property, from-

(1) the initial transferee of such transfer or the entity for whose benefit such transfer was made; or

(2) any immediate or mediate transferee of such initial transferee.

The grammar of $\S 550(a)$ is significant. "Recovery"-whatever that is-presupposes "avoidance." Avoidance is what $\S 549$ (a) refers to.

Therefore, the county might be able to sneak up from $\S 724$ (b) (3) into $\S 724$ (b) (2) in its guise as an administrative creditor. In re Navis Realty, 193 B.R. at 1005.

Alas, the following dilemma further complicates the analysis. If $A$ is under water for its secured claim, every dollar of property tax that accrues is a depreciation of $A$ 's secured claim. If the trustee does not pay the property tax currently, then $A$ can claim an offense of its right to adequate protection. The remedy for failed adequate protection is a superpriority under $\S 507$ (b). This priority outranks $\$ 507(a)(1)$. Putting all this together, every dollar of property tax that accrues generates a senior superpriority in $A$ which squeezes out the county's (and everyone else's) administrative claim. The county is effectively prevented by this from creeping out of $\S 724$ (b) (3) into $\$ 724$ (b) (2). See In re LMS Holding Co., 197 B.R. 915 (Bankr. N.D. Okla. 1996) (stating $\S 507$ (b) creditor took tax lien amount under $\S 724$ (b) (2)).

Properly, §724(b) applies indirectly in chapter 11 cases through the rule in $\$ 1129$ (a) (7)(A). Section $1129(\mathrm{a})(7)(\mathrm{A})$ implies that a chapter 11 plan need only give secured creditors what they would have received under chapter 7 . It is submitted that $\S 1129$ (a) (7) (A) makes $\$ 724$ (b) pertinent in chapter 11 cases.

${ }^{201}$ See generally David Gray Carlson, Avoidance Theory According to Steve Nickles, 22 CARDOZO L. REv. 1277 (2001); Carlson, supra note 1; Steve H. Nickles, Deprizio Dead Yet? Birth, Wounding and Another Attempt to Kill the Case, 22 CARDOZO L. REV. 1251 (2001). 
Given avoidance, recovery is merely an option for the trustee-one among many.

What, then, is recovery, and how is it different from avoidance? In my view, "recovery" refers to the in personam liability of a nontransferee-what $\S 550$ (a) calls "the entity for whose benefit such transfer was made." The necessity of referring to the "entity benefited" was inspired by $\S 60$ of the Bankruptcy Act of 1898 , which indicated that voidable preferences include transfers for the benefit of creditors (not just transfers to creditors). ${ }^{202}$ Section 60 of the Bankruptcy Act of 1898 included a "recovery" section. ${ }^{203}$ From that one learned that voidable preferences could be recovered from transferees. ${ }^{204}$ How, then, could a trustee recover from the person benefited who was never a transferee?

To solve this riddle, courts invented the so-called "two transfer" theory. The transfer to a creditor was one transfer. The "benefit" felt by a non-transferee was yet another. This two transfer theory was memorably demolished by Judge Frank Easterbrook in Levit $v$. Ingersoll Rand Financial Corp. ${ }^{205}$

In 1977, through the inclusion of $\S 550$ (a) in the Bankruptcy Code, the drafters were able to legislate away the need for the "fiction" that made non-transferees into transferees. The point of $\S 550$ (a) was to make clear that the "person benefited" is a proper party, not just in voidable preference cases but in cases involving many other avoidance powers as well. ${ }^{206}$

${ }^{202}$ Bankruptcy Act of 1898 , ch. $541, \S 60,30$ Stat. 544 (repealed by Bankruptcy Reform Act of 1978, Pub. L. No. 95-598, tit. IV, § 401 (a), 92 Stat. 2549, 2682).

203 See id.

204 According to $\$ 60(\mathrm{~b})$ :

Any such preference may be avoided by the trustee if the creditor receiving it or to be benefited thereby... has, at the time when the transfer is made, reasonable cause to believe that the debtor is insolvent. Where the preference is voidable, the trustee may recover the property or, if it has been converted, its value from any person who has received or converted such property....

Id. (emphasis added).

${ }^{205} 874$ F.2d 1186 (7th Cir. 1989). The case is universally known as the Deprizio case after the name of the debtor-in-possession.

206 This unique purpose was effectuated recently in In re Dybalski, 316 B.R. 312 (Bankr. S.D. Ind. 2004), where the debtor wrote prepetition checks that were honored postpetition. The bank that honored the checks was protected by $\S 542(\mathrm{c})$, but the merchants paid by the checks were not. Id. at 315,316 . Instead of pursuing the merchants, the trustee was permitted to sue the "persons benefited"-the debtors themselves. Id. at 316-17. Incidentally, the merchants did not violate the automatic stay in Dybalski. Id. at 316. Bankruptcy Code $\S$ 362 (b) (11) exempts from the automatic stay "the presentment of a negotiable 
Nevertheless, $\S 550$ (a) confusingly sets forth defenses that only transferees can use. For example, a transferee of a transferee (but not the initial transferee) has a "good faith transfer for value defense" under $\S 550(\mathrm{a})$. Under $\S 550(\mathrm{e})$, a good faith transferee who has invested in improvements is entitled to a lien for the lesser of cost or value added. Finally, $\S 550$ (f) gives a statute of limitations defense to "recovery" actions, which, significantly, differs from the statute of limitations in $\S 549$ (d). This might be cited by in rem and in personam defendants alike. The fact that $\$ 549$ (a) avoidance and 550 (a) recoveries have different statutes of limitations, however, proves there is a substantive difference between avoidance and recovery. The problem with the $\S 550$ defenses is that avoidance also occurs by means of $\S 551$, the lien preservation provision. According to $\$ 551$, "[a]ny transfer avoided under section... $549 \ldots$ is preserved for the benefit of the estate but only with respect to property of the estate." The $\S 550(\mathrm{a})$ defenses do not seem to apply here.

A comparison might be made between two very recent interpretations of $\S 551$ and $\S 550(\mathrm{a})$, pointing in very different directions. In Suhar $v$. Burns (In re Burns), ${ }^{207}$ a debtor granted a mortgage to a lender who did not perfect. ${ }^{208}$ The lender then sold the mortgage in the secondary market. ${ }^{209}$ The mortgage was voidable under $\S 544(\mathrm{a})(3) .^{210}$ The assignee tried to assert a valid "improvement lien" under $\S 550(\mathrm{e}){ }^{211}$ The assignor had advanced funds to retire an earlier recorded mortgage. ${ }^{212}$ Therefore, the assignee reasoned, the original lender had an "improvement" lien under Bankruptcy Code $\S 550(\mathrm{e}) .^{213}$ The Burns court, however,

\footnotetext{
instrument...." Although the stay was not violated, the merchants were nevertheless liable under $\S 549$ (a) for receivable postpetition property of the estate. Id.; see Thomas v. Money Mart Fin. Servs., 311 B.R. 75 (Bankr. W.D. Mo. 2004).

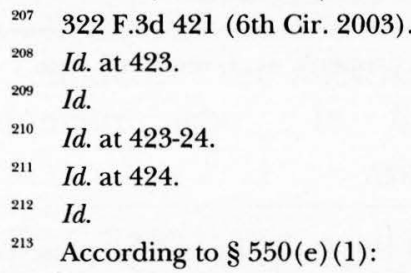

A good faith trustee from whom the trustee may recover under subsection (a) of this section has a lien on the property recovered to secure the lesser of-

(A) the cost, to such transferee, of any improvement made after the transfer, less the amount of any profit realized by or accruing to such transferee from such property; and
} 
overruled the defense because the strong arm power avoided the conveyance without any reference to $\S 550(\mathrm{a})$. The court expressly noted that $\$ 551$ independently brought the avoided lien into the bankruptcy estate, thus $\S 550$ (e) cannot be characterized as a defense to $\S 551$. $^{214}$

When, if ever, must a trustee use $\S 550(\mathrm{a})$, thereby triggering the $\$ 550$ (e) defense? Borrowing a distinction drawn from Epstein's Bankruptcy treatise, ${ }^{215}$ the Burns court declared that, when a creditor is in physical possession of the collateral to which a voidable lien has attached, the trustee must proceed under $\S 550(\mathrm{a})$ in order to "recover" the collateral. ${ }^{216}$ But this does not follow. According to the court's own logic, the trustee owned the avoided lien under $\S 551$. This lien implies the trustee's right to use, sell, or lease under $\S 363$. Why cannot the trustee simply bring a turnover action under $\$ 542(\mathrm{a})$ or (b) to vindicate this right of possession? In any case, why should a secured party who has not yet repossessed have no defenses under $\S 550$ (e), whereas an entity that has possession obtain it? This makes no sense, especially where bankruptcy policy is meant to prevent creditors from repossessing property the trustee might use, sell, or lease. ${ }^{217}$

In comparison, consider the facts of Wasserman v. Bressman (In re Bressman). ${ }^{218}$ In Bressman, $D$ allegedly sent estate funds to a Cook Islands trust. ${ }^{219}$ Needing criminal counsel, $D$ arranged for the Cook Islands trust to wire funds to his spouse's bank account. ${ }^{220}$ The spouse's bank honored the spouse's check to $D$ 's criminal counsel. ${ }^{221}$ The key to the analysis (though nowhere acknowledged) was that the bank transfers were presumably made under the shelter of $\S 542$ (c). If the banks were (as was likely) unaware that they were transferring estate funds, then $\S 542$ (c) applied to validate the transfers provisionally. The trustee therefore had to bring a

(B) any increase in the value of such property as a result of such improvement of the property transferred.

Id. at 428.

2152 DAVID G. EPTSEIN ET AL., BANKRUPTCY $§ 6-79$ (1992).

216 In re Burns, 322 F.3d at 428.

217 United States v. Whiting Pools, Inc., 462 U.S. 198 (1983) (noting lawful repossession can be undone through turnover proceeding).

218327 F.3d 229 (3d Cir. 2003).

219 Id. at 235. Or so the court assumed, for the purpose of analysis.

220 Id. at 234 .

$221 \quad I d$. 
$\S 549$ (a) action against criminal counsel to recover the estate funds. ${ }^{222}$ If, however, the banks knew they were transferring estate funds, then $\S 542$ (c) would not shield the transactions. The trustee could have brought a mere turnover action under $\$ 542$ (b) against the banks, to which the defenses in $\S 549$ (a) and $\S 550$ certainly would not apply.

Assuming that turnovers under $\S 542$ (a) or (b) were off the table because a bank made a conveyance covered by $\S 542$ (c), the trustee had to "avoid" the transfer under $\S 549(\mathrm{a})$. No defense existed for criminal counsel under $\S 549$. Therefore, the transfer was "avoided" under $\S 549(\mathrm{a})$ and "preserved" under $\S 551 .^{223}$ As such, the funds were part of the bankruptcy estate under $\S 541(\mathrm{a})(4)$.

Given that the transfer was now "avoided," "preserved," and made part of the bankruptcy estate, ${ }^{224}$ it ought to have been possible for the trustee to demand a turnover of the funds under $\S 542$ (a) or (b). As to a turnover under $\S 542$ (b), the $\S 550$ defenses would not apply. Nevertheless, the Bressman court ruled that the trustee could recover only via $\S 550(\mathrm{a}) .^{225}$ On this premise, criminal counsel could and did assert a bona fide transferee defense under $\$ 550(\mathrm{~b})$ because counsel was the transferee of a transferee of potentially voidable funds. ${ }^{226}$

The Bressman result can be defended as within the suggestion urged by the Burns court. Because criminal counsel was "in possession" of funds, the trustee had to "recover" under $\$ 550$, avoidance would not suffice. Under Burns, avoidance without recovery works only when the trustee is already in possession-not when some other entity has possession. ${ }^{227}$ Yet $\S 551$ works quite well to circumvent $\S 550$ (a) altogether, even where counsel's claim to the cash was possessory and absolute.

Whether $\S 550$ defenses are available in $\S 549$ (a) cases depends on whether the trustee or some other entity is in possession, if Burns is followed. Yet another level of complexity is added by the automatic stay. In Bressman, criminal counsel presumably

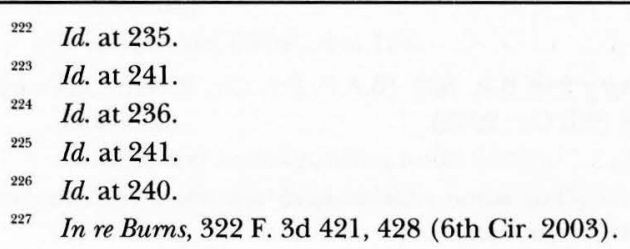


committed acts "to obtain possession of property of the estate or of property from the estate or to exercise control over property of the estate."228 For example, criminal counsel endorsed the spouse's check and sent it to their bank for deposit. ${ }^{229}$ Were these not "void" acts, suggesting that the trustee could recover the amounts voidably deposited? Obviously, the Bressman result works only if defenses to $\S 549$ (a) avoidance are considered implicit exceptions to automatic stay voidness.

\section{POSTPETITION TRANSFERS IN THE NinTH CirCUIT}

Ninth Circuit law on postpetition transfers is particularly acephalous. The exceptionally interesting case of Beeler $v$. Jewell (In re Stanton) ${ }^{230}$ sheds some light on $\S 549$ (a) avoidance, as well as on the nature of the bankruptcy estate itself. Before we can examine this case, we must come to grips with the lamentable vocabulary that has grown up in the Ninth Circuit. The Ninth Circuit has proved a leader in postpetition jurisprudence, perhaps because its terminology is so mystifying.

\section{A. The Vocabulary of Postpetition Transfers}

By now, it should be apparent that the Ninth Circuit's mediation in Lusardi of the collision between $\$ 549(\mathrm{a})$ and the automatic stay has been unsatisfactory. But, casting the automatic stay aside, its interpretation of $\S 549$ (a) is also deeply problematic. The oft-cited case of Phoenix Bond E Indemnity Co. v. Shamblin (In re Shamblin) $)^{231}$ must be especially singled out for infusing doubtful metaphysics into an environment already rife with contradiction. A thorough understanding of Shamblin is required if we are to understand what follows.

Shamblin involved an Illinois property tax $\operatorname{lien}^{232}$-a creature so unusual that it is not surprising the Ninth Circuit was baffled by it.

228 U.S.C. $§ 362(\mathrm{a})(3)$.

229 In re Bressman, $327 \mathrm{~F} .3 \mathrm{~d}$ at 233.

230303 F.2d 939 (9th Cir. 2002), aff'g 248 B.R. 823 (B.A.P. 9th Cir. 2000). An earlier withdrawn opinion exists at 285 F.3d 888 (9th Cir. 2002).

${ }^{231} 890$ F.2d 123 (9th Cir. 1989).

${ }^{292}$ See Flaccus, supra note 109, at 86 ("For some reason there are more tax avoidance court decisions under Illinois law than any other state."). 
Under Illinois law, ${ }^{233}$ when a county assesses a tax and obtains a "lien," the county enforces it by selling a "certificate of purchase" which eventually entitles the buyer to a fee simple estate, free and clear of all encumbrances if the amount bid is not redeemed by the debtor or some junior encumbrance. Oddly, the bidders compete by offering the lowest redemption price. If no one redeems, the buyer of the certificate of purchase has the right to a tax deed, issued by a court clerk. Once issued, the buyer must record the tax deed within one year. Upon recordation, the buyer owns a fee simple estate.

In Shamblin, the county had a prepetition tax lien. Before it could foreclose, $D$ filed a bankruptcy petition. ${ }^{234}$ Without knowledge of the bankruptcy petition, the county sold a certificate of purchase to $X .^{235}$ Under Illinois law, $D$ had two years to redeem. ${ }^{236} D$ never did, and $X$ eventually obtained a deed. ${ }^{25}$

In that the county was ignorant of the bankruptcy proceeding, the county was authorized by $\S 542$ (c) to make the conveyance, and $X$ was authorized to receive it. Properly, there should have been no mention of the automatic stay in this case. ${ }^{238}$ Rather, it should have been a $\S 549$ (a) case pure and simple.

The bankruptcy court denied the trustee's motion to set aside the sale on the grounds that $X$ had a statute of limitations defense under $\S 549$ (d) because more than two years had passed between the sale and the trustee's adversary proceeding. ${ }^{239}$ Although the bankruptcy court thought that the automatic stay was violated, it thought $\S 549$ (d) was relevant to automatic stay theory. ${ }^{240}$ Of course, the automatic stay can be retroactively annulled. Perhaps the secret meaning of the bankruptcy court's ruling was that the bankruptcy

\footnotetext{
${ }^{233}$ The following description of Illinois property tax liens is drawn from McKeever $v$. McClandon (In re McKeever), 132 B.R. 996 (Bankr. N.D. Ill. 1991).

${ }^{234} D$ 's bankruptcy was a chapter 11 proceeding, so $D$ was also the bankruptcy trustee. Nevertheless, I will refer to "the trustee" as a person separate and apart from $D$ for purposes of dramatic exposition.

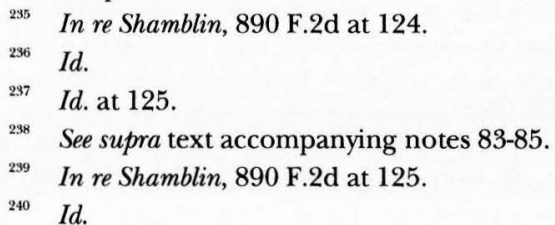


court was really annulling the stay and validating the tax sale in order to vindicate the statute of limitations. ${ }^{241}$

The Bankruptcy Appellate Panel reversed. ${ }^{242}$ It thought that the sale was void for violating the automatic stay and that $\S 549$ (d) could not serve as a defense to a principle arising from $\S 362(\mathrm{a}) .{ }^{243}$ Nevertheless, the appellate panel awarded a lien to $X$ under the last sentence of $\S 549$ (c), which provides:

A good faith purchaser without knowledge of the commencement of the case and for less than present fair equivalent value has a lien on the property transferred to the extent of any present value given, unless a copy or notice of the petition was so filed ${ }^{244}$ before such transfer was so perfected.

In this the appellate panel fell into contradiction. How could $\S 549$ (c) be a defense to an automatic stay theory when $\S 549$ (d) (the statute of limitations) was not?

The Ninth Circuit reversed again and was no less contradictory than the lower courts. Ostensibly, it declined to rule that the automatic stay overwhelms $\S 549$ defenses, leaving that possibility open. ${ }^{245}$ Rather, it held:

Section 549 does not apply. The tax sale as conducted under Illinois law was not a "transfer of property of the estate" under $\$ 549$. Because an Illinois tax sale gives the purchaser only a lien on the property the purchaser does not obtain a transfer of property of the estate, but obtains only a claim against it. Because the tax sale was not a "transfer of property of the estate" under subsection (a), none of the provisions of $\S 549$ apply. The exceptions to $\S 549$, including

${ }^{241}$ This possibility was rejected by the Ninth Circuit because the bankruptcy court mentioned only $\S 549$ (d) and said nothing of retroactive annulment. The court also ruled that, if this was the bankruptcy court's intent, it would have been an abuse of discretion. Id. at 126.

${ }^{242}$ Id. at 125 .

243 Id.

${ }^{244}$ That is, filed in the local real estate records.

${ }^{245}$ Id. at 127 n.5. The Ninth Circuit has since ruled definitively that the automatic stay always erases $§ 549$ (c) defenses. 40235 Wash. St. Corp. v. Lusardi, 329 F.3d 1076 (9th Cir. 2003). 
the provision granting a lien to certain good faith purchasers, cannot, therefore, apply. ${ }^{246}$

This is the statement that has spawned confusion in the Ninth Circuit. Can it be true that, if $X$ has a "lien," $X$ has no property interest ${ }^{247}$ Surely a lien is an in rem interest, and lien creation the archetypical transfer of property. ${ }^{248}$ For example, suppose a creditor obtains a judicial lien the day before a bankruptcy petition. This is the most brazen voidable preference imaginable. But voidable preference requires a "transfer of an interest of the debtor in property. ${ }^{249}$ Yet, under Shamblin, there is no voidable preference because lien creation is not a transfer of debtor property. ${ }^{250}$

Furthermore, under Illinois law, surely the county sells something to $X$ at a foreclosure sale. In particular, $X$ buys a certificate of purchase that will ripen into a fee simple interest if $X$ is not paid off. This is an interest that exceeds what the county had prior to the sale. ${ }^{251}$ To call this thing a lien, however, as the Shamblin court did, is confusing. It seems more in the nature of a conditional future interest that becomes possessory upon $D$ 's failure to redeem.

246 In re Shamblin, 890 F.2d at 127 (footnotes and citations omitted).

${ }^{247}$ One court has indeed suggested "[t]he Certificate of Purchase . . does not operate to transfer any title, legal or equitable, to the tax purchaser." In re McKeever, 132 B.R. 996, 1006 (Bankr. N.D. Ill. 1991).

248 In re Pointer, 952 F.2d 82 (5th Cir. 1992) ("Attachment of a lien on property of the estate is clearly a 'transfer' of property.").

24911 U.S.C. $\$ 547$ (b).

$250 \quad$ In re Shamblin, 890 F.2d at 127.

${ }^{251}$ Courts routinely hold that the automatic stay does not stop redemption periods from lapsing-though $\S 108$ (b) has that effect for sixty days. E.g., Heikkila v. Carver (In re Carver), 828 F.2d 463 (8th Cir. 1987). The facts in Shamblin, however, are different. In Shamblin, $X$ sought to start the redemption period running. $890 \mathrm{~F} .2 \mathrm{~d}$ at $124-25$. The commencement of the period (by obtaining a certificate of purchase) does potentially violate the automatic stay-though, in Shamblin, $X$ could plausibly claim immunity from the automatic stay under $\S 542(\mathrm{c})$.

For a case holding that the automatic stay does not stop Illinois tax redemption periods from running, provided the certificate of purchase was obtained prepetition, see Smith $v$. Phoenix Bond $\mathcal{E} \mathcal{F}^{2}$ Indem., 288 B.R. 793 (N.D. Ill. 2002). Interestingly, in Smith, $X$ was careful to move for relief from the automatic stay in order to obtain the tax deed. Id. at 795 .

Confusingly, in In re Natchez Corp., 953 F.2d 184 (5th Cir. 1992), the court implied that obtaining a tax deed after the redemption period was a new transfer under $\S 549$ (a). As such, the issuance of the tax deed could be avoided unless $X$ has a defense. Yet, since $X$ typically does not pay the value of the fee simple interest and because $X$ may know of the bankruptcy proceeding at the time the redemption period lapses, it would appear that $X$ has no defenses. Perhaps the automatic stay does indirectly extend the redemption period under the Natchez case. 
A lien, in contrast, is a "charge against or interest in property to secure payment of a debt or performance of an obligation.

The true meaning of the above passage, however, is supplied by one of the footnotes. The Illinois tax foreclosure sale conveyed nothing because of the automatic stay. ${ }^{253}$ Since the automatic stay voided the sale, $X$ received nothing. In short, it appears that automatic stay theory decided the case, and $\$ 549$ was simply irrelevant. This footnote, ${ }^{254}$ however, is at odds with the Ninth Circuit's declaration that it was not ruling that automatic stay theory preempts $§ 549$ defenses. ${ }^{255}$

Shamblin is a difficult opinion, ${ }^{256}$ and, predictably, it has generated confusion. In Schwartz v. United States (In re Schwartz), ${ }^{257}$ the Ninth Circuit suggested that $\S 549$ (c) is indeed a defense to automatic stay theories. This is not an unfair reading of Shamblin. But its exact language has further confused matters. In describing Shamblin, the Schwartz court noted, "[w]e held that the tax sale was not a transfer of property of the estate under section 549, reasoning that the sale created only a lien on the property and did not actually transfer the property itself for purposes of section 549." ${ }^{, 58}$ Once

252 11 U.S.C. $\$ 101(37)$.

253 The Shamblin court noted:

This court has consistently treated the creation of liens on the debtor's property as a transfer. See, e.g., In re Wind Power Systems, Inc., 841 F.2d 288, 291-92 (9th Gir. 1988); Bass v. Stodd, 357 F.2d 458, 464-65 (9th Cir. 1966). These cases, however, define "transfer" in the context of prepetition, as opposed to post-petition, transactions. The Shamblins and their creditors were fully protected against the post-petition creation of a lien under $\S 362(\mathrm{a})(4)$. "Transfer" under $\S 549$, therefore, need not include the lien created by the Illinois tax sale.

890 F.2d at 127 n.7. For a similar case that reaches this result without contradictory metaphysics, see Venn v. Bazzel (In re Lanbert), 273 B.R. 663 (Bankr. N.D. Fla. 2002).

${ }_{254}$ In re Shamblin, 890 F.2d at 127 n.7.

${ }_{255}$ Id. at 127.

${ }^{256}$ At least one court has announced unhappiness with the above formulation from Shamblin:

The court is not altogether comfortable with this interpretation. While it reaches the correct result, it does so by use of a distinction which may run contrary to the broad definition of property of the estate, and may not be consistent as a matter of law from state to state. More importantly, this solution fails to address the fundamental question, raised by appellants, of the interrelationship between $\S 362$ (a) and other Bankruptcy Code sections which cannot always be resolved by concluding that a post-petition transfer was not of property of the estate.

Garcia v. Phoenix Bond \& Indem. Co. (In re Garcia), 109 B.R. 335, 338 (Bankr. N.D. Ill. 1989).

${ }^{257} 954$ F.2d 569 (5th Cir. 1991).

${ }^{258} \quad I d$. at 574 . 
again, the Ninth Circuit repeated the proposition that lien creation is not a transfer of debtor property. ${ }^{259}$ What the Schwartz court should have said about Shamblin is that, because of the automatic stay, the county's foreclosure sale could not convey property of the bankruptcy estate, but it could convey the county's own lien (i.e., subrogation), which $X$ could then assert in the bankruptcy proceeding. Nothing in the automatic stay prevents $A$ from assigning her claim to $X$ after $D$ has filed for bankruptcy. ${ }^{260}$

The Ninth Circuit itself had earlier recognized that lien creation is a postpetition transfer. In Official Committee of Creditors $v$. Union Bank (In re Texas Research, Inc.), ${ }^{261} \mathrm{D}$, an involuntary debtor, granted a security interest to $X$ in exchange for a loan. ${ }^{262}$ Under Shamblin and Schwartz this lien should have been considered "void," but the Ninth Circuit ruled the lien was defended under $\S 549$ (b). Such a holding directly contradicts Shamblin as reinterpreted by Schwartz. Under Texas Research, at least, postpetition lien creation is a valid transfer of property of the bankruptcy estate, and the trustee must step forward and avoid it, if she can.

The meaning of Shamblin grows yet more confusing after Thompson v. Margen (In re McConville), ${ }^{263}$ where a debtor filed for chapter 11 protection and then, without court permission, granted a mortgage to a lender who was unaware of the bankruptcy. ${ }^{264}$ According to the McConville court, " $\mathrm{t}]$ he Trustee argued that he might avoid [the lien] under $\S 549$ (a) ... [W] e find them both blocked by our precedents ... which simply hold that the creation of a lien does not transfer property for purposes of $\S 549$.",65 The court went on to find the mortgage valid to the extent that funds had actually been advanced, but invalid as to interest or attorneys' fees, because this was unauthorized extension of credit to the debtor. $^{266}$ In short, nunc pro tunc approval, or after-the-fact ratification under $\S 364$, was granted to preserve part of the postpetition mortgage lien.

259 Id

260 See supra text accompanying notes 127-37.

261862 F.2d 1161 (5th Cir. 1989).

$262 \quad$ Id. at 1162.

269110 F.3d 47 (9th Cir. 1996).

264 Id. at $47-48$.

${ }_{265}^{265}$ Id at 49 (citing In re Schwartz, 954 F.2d at 574); see also In re Shamblin, 890 F.2d 123, 127 (9th Cir. 1989).

266 In re McConville, 110 F.3d at 50. 
What the McConville court should have said was that the creation of a lien is always a transfer of property. Because the debtor-in-possession had no authority to convey the bankruptcy estate (without court approval), the debtor-in-possession could do nothing in derogation of the bankruptcy estate. Nothing in McConville was "avoided." The debtor-in-possession simply lacked power to create a lien in the bankruptcy estate. This lack of authority was partially remedied by the McConville court, which elected to ratify the debtor-in-possession's action under $\S 364$ (c) with regard to part of the mortgage lien. Ratification, not partial avoidance, explains the result in McConville. ${ }^{267}$

Finally, note should be taken of 40235 Washington Street Corp. $v$. Lusardi. ${ }^{268}$ Acknowledging that Ninth Circuit law had become a hopeless mess, Lusardi emphatically renounced the Schwartz dictum holding $\S 549$ (c) to be a defense to automatic stay voidness. ${ }^{269}$ The Shamblin confusion was left uncorrected and did not figure in the case. These remarks will help us understand some otherwise

${ }^{267}$ If McConville takes the position that $\$ 549$ (a) does not pertain to the unauthorized creation of a lien by a debtor-in-possession, In re Garcia, 109 B.R. 335 (Bankr. N.D. Ill. 1989), takes the opposite view. The Garcia court held that automatic stay voidness was entirely unrelated to $\S 549$ (a) avoidance, and for this reason the $\S 549$ (d) statute of limitations was irrelevant. Id. at 339. In so ruling, the court concluded that the real purpose of $\$ 549$ (a) was to attack unauthorized conveyances by a bankruptcy trustee. Id.; accord, Sapir v. C.P.Q. Colorchrome Corp. (In re Photo Promotion Assocs.), 881 F.2d 6 (2d Cir. 1989) (finding that where debtor-in-possession made unauthorized contract for future credit, trustee must avoid it under $\S 549$ (a)); In re Servico, Inc., 144 B.R. 933, 936 (Bankr. S.D. Fla. 1992). Because this possibility preserved a utility for $\S 549$ (d), the Garcia court felt it was free to rule that $\S 549$ (d) was irrelevant to automatic stay voidness. 109 B.R. at 340.

In my opinion, both views are wrong. If a trustee makes an unauthorized conveyance, then it has no effect. The bankruptcy estate recovers the item transferred not because of avoidance, but because the bankruptcy estate still owns it. There is no need to refer to the automatic stay or avoidance when a bankruptcy trustee makes an unauthorized conveyance from the bankruptcy estate. If $\S 364$ has a function, it is to grant the bankruptcy court the power to ratify unauthorized acts of a bankruptcy trustee to the extent justice requires. See supra text accompanying note 91.

Compare the highly similar In re Cybridge Corp., 304 B.R. 681 (Bankr. D.N.J. 2004), aff'd, 312 B.R. 262 (D.N.J. 2004), discussed supra text accompanying notes 68-82. This case also represented the unstrained quality of mercy, but not in terms of ratification. Rather, the Cybridge court ruled that every new advance was a reimbursement for receivables earlier collected. 304 B.R. at 691 . It is possible to view Cybridge as undercutting the law of the unauthorized postpetition loan.

${ }^{268} 329$ F.3d 1076 (9th Cir. 2003).

$269 \quad$ Id. at 1082. 
incomprehensible moments in another important Ninth Circuit case-Beeler v. Jewell (In re Stanton). ${ }^{270}$

\section{B. The Stanton Case and $\$ 549$ Avoidance}

In Stanton, $D$ granted a real estate mortgage to $A$ for future discretionary advances that $A$ might make to $D$ 's wholly owned subsidiary ( $S "$ "). ${ }^{271}$ Subsequently, $D$ filed for chapter 11 bankruptcy, which was soon converted to chapter $7 .{ }^{272}$ All the while, $A$ continued to make discretionary advances to $S$, which was not bankrupt. The trustee brought an adversary proceeding, seeking a declaration that $A$ 's advances to $S$ did not encumber the real estate now in the bankruptcy estate. ${ }^{273}$

Proper analysis of the trustee's claim requires a review of Washington's ambiguous law of the discretionary future advance. Prior to 1973 , discretionary advances created only junior security interests. ${ }^{274}$ Thus, if $D$ conveyed a senior mortgage to $A$ and a junior mortgage to $B, A$ 's subsequent discretionary advance was in third place behind $B$ 's mortgage. This was the holding in National Bank of Washington v. Equity Investors, Inc. ${ }^{275}$

In 1973, the Washington legislature reformed its mechanics' lien law. Under the reform, mechanics' lienors gained a "stop notice" right: If mechanics notify construction lenders that they are unpaid, construction lenders are obliged to send committed funds directly to the unpaid mechanics' lienor. ${ }^{276}$ In connection with this, the legislature enacted the following mysterious provision:

Except as otherwise provided in RCW $60.04 .061^{[277]}$ or $60.04 .2211^{[278]}$ any mortgage or deed of trust shall be prior to all liens, mortgages,

${ }^{270} 303$ F.3d 939 (9th Cir. 2002), aff'g 248 B.R. 823 (B.A.P. 9th Cir. 2000). An earlier withdrawn opinion exists at 285 F.3d 888 (9th Cir. 2002).

271303 F.3d at 940 .

272 Id.

273 Id.

274 Nat'l Bank of Wash. v. Equity Investors, Inc., 506 P.2d 20, 26-26 (Wash. 1973).

${ }_{275}$ Id. at 44-45. If, however, the lender has committed to advance funds, the committed advances are senior. John M. Keltch, Inc. v. Don Hoyt, Inc., 483 P.2d 135 (Wash. App. 1971). In this respect, Washington mortgage law precisely replicates the U.C.C. rules pertaining to discretionary and committed lenders. Carlson \& Shupack, supra note 167, at 346-59.

${ }^{276}$ Currently, this rule is codified at title 60 , section 04.221 of the Washington Revised Code ("RCW").

${ }^{277}$ This provision states that a mechanics' lien is senior if recorded before a mortgage. 
deeds of trust, and other encumbrances which have not been recorded prior to the recording of the mortgage or deed of trust to the extent of all sums secured by the mortgage or deed of trust regardless of when the same are disbursed or whether the disbursements are obligatory. ${ }^{279}$

Notice that this statute seems to empower $A$ to make senior discretionary advances against any intervening encumbrance, even though the section is buried in the mechanics' lien provisions. An early commentator assumed that the universal meaning of the statute was fully intended-that $A$ is now empowered to make senior discretionary advances. ${ }^{280}$ Another commentator has hinted tentatively that RCW 60.04.226 subordinates only mechanics' lienors to the discretionary advances of construction lenders. ${ }^{281}$ This last view is not implausible in that mechanics' lienors are given "stop notice" rights against construction lenders, which divert future advances to the mechanics' lienors directly. This valuable right could have been a trade-off for a guarantee that construction advances would otherwise be senior to intervening mechanics' liens. Beyond this, nothing is known about the state of Washington law. The federal courts therefore found themselves in the position of making an "Erie guess" then applying acephalous bankruptcy law to it.

\section{In the Bankruptcy Court}

In his opinion favoring avoidance, Bankruptcy Judge John Rossmeissl assumed (sub silentio) that RCW 60.04.226 rendered $A$ 's postpetition advances senior as a matter of Washington law. According to Judge Rossmeissl, "[t]he effect of each advance was to increase the amount of debt secured by $[D$ 's] residence and thus decrease the bankruptcy estate's equity in the residence. Each advance was a transfer of the estate's equity to $[A] .{ }^{\prime 283}$ Obviously, A's

278 This is the "stop notice" provision.

279 RCW 60.04.226 (2000).

280 Richard Paroutaud, Mechanics' Liens: The "Stop Notice" Comes to Washington, 49 WASH. L. REV. 685 (1974).

${ }^{281}$ William B. Stoebuck, 18 Wash. Pract. Real Estate: Transactions $\$ 17.25$ (2002 Pocket Part).

${ }^{282}$ McMahan v. Toto, 311 F.3d 1077, 1080 (11th Cir. 2002).

${ }^{283}$ Beeler v. Stanton (In re Stanton), 239 B.R. 222, 232 (Bankr. E.D. Wash. 1999) (citing 
advances decrease the bankruptcy estate's equity only if RCW 60.04.226 supplies the rule.

Consistent with RCW 60.04.226, $A$ had argued that its postpetition lien was actually a prepetition lien because any advance "related back" to the creation of the lien. ${ }^{284}$ This was the Gilmore "unitary" view, which holds that liens are qualitative only-not quantitative. ${ }^{285}$ Accordingly, a new advance is not a new lien. ${ }^{28}$

Judge Rossmeissl rejected $A$ 's argument, but he did not altogether reject the unitary view. According to Judge Rossmeissl, $A$ 's prepetition lien had fallen to zero and was revived by a future advance. ${ }^{287}$ Because a lien that is quantitatively zero is no lien at all, ${ }^{288}$ the future advance created a new postpetition lien that the trustee could avoid entirely. ${ }^{289}$ This view is less than the "multiple"

Kearns Motor Co. v. Cimino (In re Dreiling), 233 B.R. 848 (Bankr. D. Colo. 1999)). In Dreiling, $D$ owned $75 \%$ of the outstanding shares in a closely held corporation. 233 B.R. at 857. The other $25 \%$ was owned by a family trust. Id. After D's chapter 7 bankruptcy commenced, the corporation watered the stock (now owned by the bankruptcy estate) so that the bankruptcy estate owned only $43.5 \%$. Id. at 862 . The Dreiling court ruled that the dilution of the stock was a postpetition transfer that was void under $\$ 549$ (a). Id. at 863 .

It is very hard to justify the conclusion that property of the estate had been "transferred." Rather, the issuer of the trustee's shares took an action which rendered the trustee from a majority to a minority shareholder. Arguably, it is not even clear that this action harmed the value of the trustee's shares because the new shares may have been sold for fair value. Although the power of a corporation to reduce the value of the trustee's shares is problematic, it is not clear that $\S 549$ (a) is the tool by which to accomplish justice.

${ }^{284}$ In re Stanton, 239 B.R. at 226-27.

${ }^{285}$ GILMORE, supra note $181, \S 35.6$, at 935.

286 Judge Rossmeissl describes this argument as follows: " $[A]$ argues that . . its lien passes through the bankruptcy and is unaffected by the discharge of the debtors personal liability." In re Stanton, 239 B.R. at 228-29. On appeal, this will be referred to A's $\S 506$ (d) argument. According to $\$ 506(\mathrm{~d})(2), A$ 's lien is void if it secures something other than an allowed secured claim (i.e., a claim for which there is no proof of claim) unless "such claim is not an allowed secured claim due only to the failure of an entity to file a proof of such claim under section 501 of this title." 11 U.S.C. $§ 506$ (d) (2) (2000).

${ }^{287}$ In re Stanton, 239 B.R. at 228.

${ }^{288}$ In other words, liens are merely quantitative and not qualitative. This is a common bankruptcy misconception, as where courts rule that $\S 1322$ (b) (2)'s protection of home mortgages does not apply if the mortgage is entirely under water, as a lien with no value is the same as no lien at all. For more on this misconception, see 2 GILMORE \& CARLSON, supra note $57, \S 27.09$.

${ }^{289}$ In re Stanton, 239 B.R. at 228-29. By holding that a lien that falls to a quantitative zero is no lien at all, Judge Rossmeissl puts himself in contradiction with Dick Warner Cargo Handling Corp. v. Aetna Business Credit, Inc., 746 F.2d 126 (2d Cir. 1984). In Dick Warmer, a judicial lien creditor levied upon surplus cash controlled by the secured party. Id. at 128. The secured party refused to hand it over. Id. Instead, the secured party incurred attorneys' fees defending the fund. Id. Ironically, in defending the fund, the secured party destroyed the 
view; it implies that if $A$ had kept one dollar of prepetition debt outstanding, the entire postpetition advance would relate back to the prepetition amount. Such an implication would make the Washington law of future advances capricious indeed. Why should there be one rule if one dollar of debt is outstanding and another if no debt is outstanding? It would have been better if Judge Rossmeissl had adopted the multiple theory in its entirety. As it stood, however, Judge Rossmeissl found A's advances genuinely postpetition events, creating senior liens on property of the bankruptcy estate. ${ }^{290}$

In addition to finding $A$ was empowered to make senior advances, Judge Rossmeissl ruled that the security agreement with $D$ was a "financial accommodation" contract that was automatically rejected under Bankruptcy Code $\S 365$ (c) (2). ${ }^{291}$ For those who are pristine about their logic, this holding-undoubtedly correctcontradicts the assumption that postpetition advances are capable of encumbering property of the bankruptcy estate. Automatic rejection of a financial accommodation contract has the effect of disaggregating the security agreement and the advances. ${ }^{292}$ As a result, the advances were not "under the security agreement" and therefore did not constitute perfecting events within the meaning of $\S 546$ (b). Nor did they violate the automatic stay for the same reason. Indeed, the advances created no interest in property of the bankruptcy estate at all if the executory contract is viewed as automatically rejected in $D$ 's bankruptcy.

Nevertheless, according to Judge Rossmeissl the advances did create perfected security interests in property of the bankruptcy estate, which the trustee could avoid under $\S 549(\mathrm{a}) .^{293}$ But if this is so, the future advances constituted $\$ 546$ (b) perfection events. Since these events are privileged against the automatic stay and also

fund. Ultimately, the secured party prevailed, even though the judicial lien predated the attorneys' fees. Id. at 135 . Thus, Dick Warner followed the unitary view for nonadvance obligations, even while the 1972 amendments dictated the multiple view for actual advances. If Dick Warner had adopted Judge Rossmeissl's zero quantity thesis, the judicial lien creditor would have prevailed over post-garnishment attorneys' fees. See Schroeder \& Carlson, supra note 186.

290 In re Stantom, 239 B.R. at 235.

291 Id. at 229-31.

${ }^{292}$ See supra text accompanying notes 190-91. It should be emphasized that "automatic rejection" disaggregates the postpetition advance from the security agreement whether the postpetition advance is "committed" or entirely discretionary.

293 In re Stanton, 239 B.R. at 231-33. 
immune from $\S 549$ (a) avoidance, the admission of $A$ 's presumptive seniority to the bankruptcy trustee properly destroys all possibility of avoidance.

Judge Rossmeissl did at least rule that $A$ did not violate the automatic stay by making advances to $S^{294}$ However, his reasons for so ruling are unpersuasive: "The debtors['] active willing participation in the factoring agreement between $[A]$ and $[S]$ with knowledge and expectation that the guaranty and deed of trust were operative does not support a finding that there was a violation of the automatic stay. ${ }^{, 295}$ This reasoning, standing alone, cannot suffice, because a debtor always actively participates in a prepetition security agreement. Yet postpetition enforcement of the agreement clearly constitutes a violation of the automatic stay. ${ }^{296}$

Nevertheless, automatic rejection of the security agreement explains the result actually reached by Judge Rossmeissl. Since the postpetition advances are not "under the security agreement," they are completely impotent against and irrelevant to the bankruptcy estate. For this reason, they did not violate the automatic stay.

According to Judge Rossmeissl, the trustee had a valid § 549(a) theory against $A$ 's postpetition liens. ${ }^{297}$ But this assumption put Judge Rossmeissl in trouble with regard to $\S 348(\mathrm{~d})$, which governs the effect of converting a chapter 11 case to chapter 7 .

Section $348(d)$ is an exception to the general rule in $\S 348(a)$. According to $\S 348(a)$, the date of the original petition governs for all purposes of the converted chapter 7 case-with one exception. According to $\S 348(d)$ :

A claim against the estate or the debtor that arises after the order for relief but before conversion in a case that is converted under section 1112 , 1208, or 1307 of this title, other than a claim specified in section 503(b) of this title, shall be treated for all purposes as if such claim had arisen immediately before the date of the filing of the petition. ${ }^{298}$

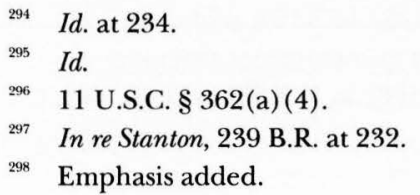


This section implies that if postpetition advances encumber estate property, then, in a converted chapter 7 case, these postpetition advances are to be considered prepetition advances. As such, they create valid prepetition liens. In short, $\S 348(\mathrm{~d})$ creates a "relation back" rule of the sort that (according to some) $\S 546$ (b) (1) embodies. ${ }^{299}$

Judge Rossmeissl refused to follow the plain meaning of this statute. Instead, he ruled that $\S 348(d)$ only means that postpetition advances are dischargeable in the chapter 7 case. ${ }^{300}$ In other words, "for all purposes" in $\S 348$ (d) really means "for purposes of the debtor's discharge under $\S 727(\mathrm{a})$ and no other." As Judge Rossmeissl put it, "[i]f section 549 is going to have any meaning, then transfers avoided under section 549 (a) should not be subject to revival under section $348(\mathrm{~d})$. $^{301}$

Ironically, if $A$ is empowered by $\S 546(b)$ to make senior advances, $\S 549$ (a) properly has no meaning because $\S 546(\mathrm{~b})$ is a defense to $\S 549$ avoidance. Equally, $\S 549$ (a) properly has no meaning if the security agreement is deemed automatically rejected in $D$ 's bankruptcy. Of course, the first view favors $A$ and the second view favors the bankruptcy trustee. But if Judge Rossmeissl had seen either of these points, he could have given full effect to the plain meaning of $\S 348$ (d) as written. The second view-the one adopted by Judge Rossmeissl-is the better one. According to this view, $A$ 's advances to $S$ are simply not covered by the security agreement, once the security agreement is rejected as a financial accommodation within the meaning of $\S 365$ (c) (2) ${ }^{302}$

In short, no matter what the Washington law of the future advance is, the trustee had no avoidance theory under either the automatic stay or $\S 549(\mathrm{a})$. Then again, he did not need one. Because the security agreement was automatically rejected under $\S 365$ (c) (2), A could not claim a senior postpetition lien against the bankruptcy estate.

299 See supra text accompanying notes 176-82.

$300 \quad$ In re Stanton, 239 B.R. at 333-34.

sol Id. at 234.

${ }^{302} I d$. at 231. 


\section{The Bankruptcy Appellate Panel}

On appeal, the Bankruptcy Appellate Panel reversed in a divided opinion. According to Judge John Ryan,

[u]nder Ninth Circuit authority, the postpetition creation of a lien on property of the estate is not a transfer of property for purposes of $\S 549 \ldots$. If the creation of a lien is not a transfer of property, then the further encumbrance of estate property based on a prepetition lien cannot be a transfer either. ${ }^{303}$

Here, the Shamblin confusion ${ }^{304}$ has made its masterpiece. It will be recalled that, according to Shamblin, postpetition lien creation is deemed not a transfer of property. ${ }^{305}$ Such liens are constantly "shamblin'" toward Bethlehem to be born (but never quite getting there). In Shamblin, however, the effect of these dubious metaphysics was to deprive $X$ of postpetition booty. Judge Ryan took Shamblin to mean the opposite. If, per Shamblin, discretionary advances create no new liens, postpetition advances must "relate back" to creation of the original mortgage. In effect, bad Shamblin metaphysics, combined with the Gilmore "unitary" theory of security interests, empowered $A$ to take senior liens against property of the bankruptcy estate for postpetition advances.

The "unitary" view espoused by Judge Ryan does not cohere with the notion that the security agreement is an automatically rejected financial accommodation contract, and indeed, Judge Ryan expressly so ruled. ${ }^{306}$ In Judge Ryan's opinion, the security agreement was in fact three agreements: (1) an agreement between $S$ and $A$; (2) $D$ 's guaranty agreement with $S$; and (3) $D$ 's mortgage agreement with $S^{307}$ Only the last agreement was at stake, in Judge Ryan's view. ${ }^{308}$ But this was no executory contract. It was an executed contract and therefore it was not rejected. This was just another way of restating Judge Ryan's "unitary" assumption that $A$ 's mortgage was entirely a prepetition lien, and no postpetition event

${ }^{303}$ In re Stanton, 248 B.R. 823, 828 (B.A.P. 9th Cir. 2000) (citations omitted).

${ }^{304}$ In re Shamblin, 890 F.2d 123 (9th Cir. 1989).

905 See supra text accompanying notes $245-50$.

${ }^{306}$ In re Stanton, 239 B.R. at 830.

s07 Id.

308 See id. 
of relevance had ever occurred. ${ }^{309}$ In short, in Judge Ryan's view, the postpetition advance of $A$ was a non-event.

Judge Ryan also disagreed as to the role of $\S 364$. According to my previous analysis, $\S 364$ plays no analytical role. ${ }^{310}$ Where a bankruptcy trustee grants unauthorized liens in exchange for loans, no transfer of the bankruptcy estate occurs. Section 364 exists to empower courts to authorize a trustee's postpetition secured lending. Judge Rossmeissl, in effect, agreed that $\S 364$ does not work; his only reference to $\S 364$ was to say that if $A$ wanted to make senior advances to $S$ at the expense of the bankruptcy estate, $A$ would have to obtain court approval under $\S 364 .{ }^{311}$ This was simply a paraphrase of the Ninth Circuit's holding in Transamerica Commercial Finance Corp. v. Citibank, N.A. (In re Sun Runner Marine, Inc.) ${ }^{312}$ where the Ninth Circuit barred assumption of a financial accommodation contract under $\S 365 .^{313}$ Under Sun Runner, any financial accommodation had to be newly created and courtapproved under $\S 364 .^{314}$

Judge Ryan took Judge Rossmeissl as using $\S 364$ as an avoidance tool: "The bankruptcy court voided $[A]$ 's lien on postpetition advances to $[S]$ because $[D]$ failed to get court approval under $\S 364(c) .{ }^{315}$ In fact, this was not so. The crux of Judge Rossmeissl's opinion was contract rejection under $\S 365$ (c), which disaggregated the advances from the security agreement. His reference to $\S 364$ was simply to explain how postpetition advances might (but did not) come to encumber the bankruptcy estate. ${ }^{316}$

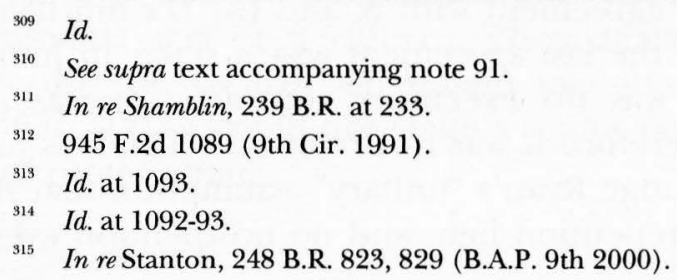

316 In comparison, Judge Perris, in dissent, apparently approved of using $\$ 364$ as an avoidance tool. Id. at 831-32; accord, In re Stanton, 303 F.3d 939, 946-47 (9th Cir. 2002) (Gould, J., dissenting). According to Judge Perris, “[i]t is irrelevant for our purposes that a contingent prepetition claim existed with respect to the postpetition loan." In re Stanton, 248 B.R. at 832. In fact, it is not irrelevant. But for executory contract rejection, the advances might have been $\S 546$ (b) events, if indeed a contingent prepetition claim existed along the lines of Judge Ryan's theory. The real reason the contingent prepetition claim is irrelevant is because $A$ 's security agreement is a financial accommodation contract automatically rejected under $\S 365$ (c) (2). 
Judge Ryan took issue with the conclusion that only $\S 364$ approval could empower $A$ 's advances to encumber the bankruptcy estate. In Judge Ryan's view, $A$ had complete freedom to make postpetition advances to the prejudice of the bankruptcy estate, even without court approval under $\S 364$. In support of his view, Judge Ryan emphasized that $S$ (not a bankruptcy trustee) sought credit. ${ }^{317}$ Advances to $S$ were therefore "outside the scope of $\S 364$ (c). ${ }^{318} \mathrm{He}$ even suggested that to require authority under $\S 364$ would be to pierce the corporate veil between $S$ and $D .{ }^{319}$

Finally, Judge Ryan remanded this case back to the bankruptcy court to consider $A$ 's claim under $\S 506(d)$. According to this provision:

To the extent that a lien secures a claim against the debtor that is not an allowed secured claim, such a lien is void unless-

(2) such claim is not an allowed secured claim due only to the failure of an entity to file a proof of such claim under section 501 of this title.

This provision states that $A$ 's lien is not void just because $A$ filed no proof of claim in $D$ 's bankruptcy. What claim $\operatorname{did} A$ have to make under $\S 506(d)$ ? In effect, $A$ 's claim under $\$ 506(d)$ was the very unitary theory of liens that Judge Ryan fully adopted. Judge Ryan's theory of the case was that the qualitative nature of $A$ 's mortgage lien was "locked in" prior to the bankruptcy petition. ${ }^{320}$ Accordingly, this lien passed through bankruptcy unaffected, permanently empowering $A$ to make senior advances in derogation of the bankruptcy estate.

In Judge Ryan's view, ${ }^{321}$ Judge Rossmeissl never considered this \$506(d) point, but Judge Ryan was wrong. Judge Rossmeissl had

In re Stanton, 248 B.R. at 829.

$318 \quad I d$.

319 Id. at 829 n.10. This is correctly dismissed by Judge Perris in dissent as overkill. Indeed, a bankruptcy court may find cause to permit financing of a nonbankrupt subsidiary or parent on the credit of the bankruptcy estate. See In re Sun Runner Marine, Inc., 945 F.2d at 1094 (implying as much). Such authority, appropriate if the bankruptcy estate is benefited, would not constitute piercing the corporate veil. Nevertheless, the Ninth Circuit would repeat the "piercing the veil" canard. In re Stanton, 303 F.3d at 942.

${ }_{320}$ In re Stanton, 248 B.R. at 831.

${ }^{321}$ Id. at $830-31$. 
expressly ruled on this point against $A{ }^{322}$ just as Judge Ryan expressly ruled in favor of $A .^{323}$ The remand order was therefore quite unnecessary, as Judge Ryan himself had already decided the "pass through" question in $A$ 's favor. ${ }^{324}$

\section{The Ninth Circuit Opinion}

On further appeal, in two split decisions, the Ninth Circuit ostensibly affirmed. ${ }^{325}$ But in reality, the Ninth Circuit remanded to determine the true nature of Washington law. As a result, nothing was accomplished, and the courts may have to rehearse the controversy a second time. Yet the Ninth Circuit said enough to suggest that $D$ is free to make postpetition transfers of $D$ 's right to the bankruptcy surplus, even if these transfers cannot adversely affect the bankruptcy trustee's senior judicial lien.

In the first opinion (later withdrawn), ${ }^{326}$ Judge Andrew Kleinfeld made the assumption that $A$ was disempowered by Washington law from making senior advances. Yet, significantly, $A$ could obtain a junior lien on property of the bankruptcy estate. ${ }^{327}$ In short, Judge Kleinfeld assumed that the trustee was a lien creditor on $D$ 's prepetition property. Junior advances not affecting the trustee's lien were entirely permissible under Washington law. ${ }^{328}$ Thus, this junior lien successfully encumbered $D$ 's right to the bankruptcy surplus.

Subsequently, the Ninth Circuit elected to revise its opinion ${ }^{329}$ because it found itself ultimately uncertain as to the nature of Washington law-i.e., whether Washington National Bank (disempowering $A$ ) was overruled by RCW section 60.04.226 (empowering $A$ ):

[I] t may be that National Bank of Washington is either limited in the mechanics' lien context or entirely abrogated. But the parties neither briefed this issue nor addressed it in their argument to us.

\footnotetext{
${ }^{322}$ In re Stanton, 248 B.R. 222, 227 (E.D. Wash. 1999).

${ }^{323}$ Id. at 831.

324 Id.

s25 In $r e$ Stanton, 303 F.3d 939 (9th Cir. 2002), aff'g 285 F.3d 888 (9th Cir. 2002).

In $r e$ Stanton, 285 F.3d 888 (9th Cir. 2002).

327 Id. at 893.

See In re Stanton, 303 F.3d at 943.

${ }^{329} \quad$ Id. at 939.
} 
We thus need not reach the question whether any advances made post-petition are subordinate to intervening claims, and we leave that to the bankruptcy court to determine if necessary on remand. ${ }^{330}$

In fact, Judge Kleinfeld had all the materials available on Washington law before him-National Bank of Washington and RCW section 60.04.226, plus a split between two commentators. Nothing more is known of Washington law. He might have hazarded an Erie guess on the matter as accurately as anyone. ${ }^{331}$

In any event, the content of Washington law turns out to be irrelevant. Even if $A$ is empowered to make senior advances under RCW section 60.04.226, the automatic rejection of $A$ 's security agreement disaggregates $A$ 's advances from $A$ 's mortgage. The trustee needs no avoidance theory to subordinate $A$ 's lien for postpetition advances. Or, if $A$ is disempowered, the trustee likewise needs no avoidance theory to assert better rights over estate property than $A$ can claim, even if the security agreement survives automatic rejection.

Judge Kleinfeld makes no mention of autcmatic rejection under $\S 365$ (c)(2). In the absence of this ruling, state law is determinative. This oversight made it possible for Judge Kleinfeld to suggest that junior advances from $A$ to $S$ might create junior liens on property of the estate. According to Judge Kleinfeld,

[t]his does not mean that when $[A]$ loaned money to $[S]$ after [D was] bankrupt, a new lien was created on [D's] house. If National Bank of Washington $^{[332]}$ is still good law, it would mean that when these optional advances to $[S]$ were made, $[A$ 's] lien on the house, to the extent of these subsequent advances, was junior to the priority of intervening claims. National Bank of Washington thus would affect the priority of an optional lien but would not change the existence of the lien itself. ${ }^{333}$

I30 at $943-44$ (footnote omitted).

931 In his dissent, Judge Ronald Gould was willing to declare that postpetition advances to $S$ were junior to any intervening encumbrance, pursuant to National Bank of Washington. Id. at 948 n.9.

${ }_{332}$ Nat'l Bank of Wash. v. Equity Investors, 506 P.2d 20 (Wash. 1973). This case holds that $A$ 's discretionary advances are junior to intervening encumbrances. follows:

393 In re Stanton, 303 F.3d at 943 . In the withdrawn opinion, this paragraph read as

This does not mean that when $[A]$ loaned money to $[S]$ after [ $D$ was] bankrupt, a 
The vocabulary in this passage is confusing, but the intuition is sound. $A$ is simply junior to the bankruptcy estate for postpetition advances if National Bank of Washington is the law. This implies that the trustee has a senior lien on $D$ 's house and $D$ has the equity. $A$ 's postpetition advance created a lien only on $D$ 's surplus interest in the bankruptcy estate.

In Judge Kleinfeld's view, however, discretionary advances do not create new liens. ${ }^{334}$ This is the "unitary" theory of liens adopted by Judge Ryan. Under it, the originally created prepetition lien simply grows in size when a postpetition lien is given. Accordingly, $A$ had one single lien. But, according to Judge Kleinfeld, part of the lien was senior and part of it was junior to the lien of the bankruptcy trustee. ${ }^{335}$

Unless quantum mechanics apply, ${ }^{336}$ how can the same lien have two different priorities? In a Newtonian universe, it must be the case that $A$ has two liens-one senior to the trustee's hypothetical judicial lien and one junior to it. ${ }^{337}$

new lien was created on $\left[D^{\prime}\right.$ 's] house. It means that when these optional advances to $[S]$ were made, $[A$ 's] lien on the house, to the extent of these subsequent advances, was junior to the priority of intervening claims. Thus, the bankruptcy trustee was senior to $[A$ 's] lien for advances $[A]$ made after $[D]$ filed for bankruptcy. Washington law thus affects the priority of an optional lien but does not change the existence of the lien itself.

In re Stantom, 285 F.3d at 893.

S34 In re Stanton, 303 F.3d at 942.

395 Id. at 943 .

336 In quantum mechanics, all particles are everywhere all the time. Carlson, supra note 20, at 440-41. In the macro-Newtonian world, however, every lien has a unique position. ANDREW HAAS, HEGEL AND THE PROBLEM OF MULTIPLICITY 139 (2000) (“[B]eing is a result of measurement; that is, 'to be' means 'to already have a measure'-for being is merely an abstraction from concrete measurement, or a reduction and fixing of immeasurable singularity.").

${ }^{337}$ In his dissent, Judge Gould complained:

The majority attempts to distinguish between the priority given to a lien under Washington law and the attachment of the lien under state law, apparently because Washington cases use the term "priority" in discussions of liens based on optional advances and because making such a distinction provides necessary support for the majority's holding. However, nowhere does the case law distinguish between the priority to be given to a lien and the date that it attaches, and there is simply no basis to conclude that such a distinction exists, particularly in light of the axiom that the priority of a lien is determined by the date of its attachment or perfection by recordation.

In re Stanton, 285 F.3d at 897 n.7 (citation omitted). Judge Kleinfeld was obviously confused by John M. Keltch, Inc. v. Dom Hoyt, Inc., 583 P.2d 135 (Wash. App. 1971), which held that obligatory advances are senior to intervening lien creditors. This case hints that discretionary 
But $\operatorname{did} A$ violate the automatic stay in making advances to $S$ ? Appropriately, Judge Kleinfeld held no. ${ }^{338}$ This is perfectly correct under any view of the matter. Either $A$ is disempowered from making senior advances (under National Bank of Washington) or $A$ is empowered under RCW 60.04.226. If disempowered, $A$ 's advances simply have no effect on the bankruptcy estate and do not violate the stay for that reason. If empowered, $A$ falls within the purview of $\S 546$ (b) and $\S 362$ (b) (3) and is invited to use that power at will. ${ }^{339}$

Judge Kleinfeld's reasoning, however, was different. He invoked the metaphysical aid of Shamblin to describe why the automatic stay had no bite:

Violation of the automatic stay is a serious business, exposing the violator in some circumstances to punitive damages and sanctions for contempt. Banks and other lenders may well tremble at the notion that they and possibly their officers could face such severe sanctions if they lend money to a corporation one of whose shareholders has gone bankrupt. Many close corporations, such as small manufacturers and professional practices, secure debt with shareholders' property as well as corporate property. Shareholders sometimes go bankrupt while the corporation continues as a financially healthy business.

Section 362(a) (4) does not apply. That subsection stays any "act to create, perfect or enforce any lien against property of the estate." A loan of money to a debtor not in bankruptcy does none of those things, as the Bankruptcy Appeals Panel majority stressed .... The lien against $[D$ 's] house was created when they gave the factor a ... mortgage, prior to the bankruptcy filing. That was a conveyance of

advances are indeed junior. See id. at 138. Judge Gould clearly saw, however, that the rules for committed and discretionary advances are entirely separate and appropriately opposite to each other. In re Stanton, 303 F.3d at 948 n.8.

338 See In re Stanton, 303 F.3d at 942.

339 Judge Kleinfeld agreed entirely with Judge Ryan's view of the role of $\S 364$. Id. at 946 . It will be recalled that Judge Ryan ruled that $D$ did not need permission to make advances to $S$. In re Stanton, 248 B.R. at 829 . This assumes, of course, that no automatic rejection of a financial accommodation contract has occurred, so that $A$ is empowered by $\S 546(b)$ (1) to make senior advances. So empowered, $A$ needs no permission from the court under $\$ 364$ to proceed. On the other hand, if $A$ 's advances create junior liens, they do not adversely affect the bankruptcy estate and do not put funds into the bankruptcy trustee's hands. Either way, $\S 364$ drops from the equation. 
an interest in real property, namely, a lien. The subsequent advances merely affected how much money the lien secured. ${ }^{340}$

Once again, Shamblin metaphysics are on display. Under this view, no postpetition lien can ever be created on the estate, whether $A$ is empowered to give senior advances or not. A better view of the matter would have been that, if $A$ 's advances are senior, ${ }^{341}$ they are perfection events within the meaning of $\$ 362(b)(3)$ and $\S 546$ (b) (1). The stay is not violated when such perfecting events occur. Or, if $A$ 's advances create junior liens, these liens do not harm the bankruptcy estate. They merely attach to $D$ 's surplus under $\S 726$ (a) (6). As $D$ is free to convey this surplus, the automatic stay is not offended.

Finally, Judge Kleinfeld upheld Judge Ryan's remand of $A$ 's socalled $\$ 506(d)$ theory. ${ }^{342}$ Recall that this theory was simply a proxy for $A$ 's "unitary" account of Washington law. ${ }^{343}$ Since Judge Ryan adopted the unitary theory wholesale, there was no sense in remanding the $\$ 506(\mathrm{~d})$ question. But Judge Kleinfeld was genuinely agnostic about the state of Washington law. Judge Kleinfeld's remand makes more sense. ${ }^{344}$

Id. at $941-42$ (footnotes omitted).

${ }^{341}$ Seniority, of course, would mean that the security agreement was not a financial accommodation contract within the meaning of $\$ 365(\mathrm{c})(2)$. See supra text accompanying notes 188-92.

${ }^{342}$ See In re Stanton, 303 F.3d at 944.

343 See supra text accompanying notes 303-09.

${ }^{344}$ In his dissent, Judge Gould insisted that Washington law was clear. In re Stanton, 303 F.3d at 949. A could not make senior advances under the ruling of National Bank of Washingtom v. Equity Investors, Inc., and RCW 60.04.226 was not intended to overrule National Bank, but was limited to the priorities between mechanics' lienors and construction financers. Id. at 948, 948 n.9. Yet if that is the case, the automatic stay is not offended by these advances because they cannot adversely affect the bankruptcy estate. Id. at 947-48. Nor was it necessary to find, as Judge Gould did, a shadowy negative avoidance power in $\$ 364$ because the trustee's interest in the real estate is simply senior to that of $A$. Id. at 946-47. In short, it would have sufficed to assert the seniority of the bankruptcy trustee without any reference to the automatic stay or $\S 549$ (a).

Judge Gould also worried about the meaning of $\S 348(d)$, which states:

A claim against the estate or the debtor that arises after the order for relief but before conversion in a case that is converted under section 1112, 1208, or 1307 of this title, other than a claim specified in section 503 (b) of this title, shall be treated for all purposes as if such claim had arisen immediately before the date of the filing of the petition.

11 U.S.C. $\S 348(d)$. The bankruptcy court refused to follow the plain meaning of this provision. $A$ 's argument was that $\S 348(\mathrm{~d})$ turned $A$ 's postpetition advance into a prepetition advance, which would then be senior to the trustee's right. In re Stanton, 303 F.3d at 942. 
To summarize, then, the Ninth Circuit should have ruled that $A$ 's security agreement with $D$ was rejected; no advance by $A$ to $S$ could possibly fall under it to encumber property of the bankruptcy estate. But having overlooked this point, the Ninth Circuit recognized that the bankruptcy estate has a quantitative limit. $D$ always has a bankruptcy surplus right, which might be encumbered by $A$ 's discretionary advances. Under state law, these advances might be junior. Yet they still attach to $D$ 's surplus interest in the bankruptcy estate. This postpetition attachment occurs only if the strong arm theory of the bankruptcy estate is true. If the fee simple theory exists, there can be no question of $A$ 's junior status to the bankruptcy estate.

\section{CONCLUSION}

In this Article, I hoped to set out a coherent vision of postpetition transfers under $\S 549(\mathrm{a})$. What I found was complete doctrinal acephality. Postpetition transfers are subject to the overlapping theories of $\S 549$ (a) "avoidance" and automatic stay "voidness." I have struggled to reconcile these two doctrines, but my success has been modest at best. Only so many steps toward a coherent theory of this area of law are possible on the current text of the Bankruptcy Code.

After considerable cleanup, I found that the Ninth Circuit's recent opinion in Beeler $v$. Jewell (In re Stanton) ${ }^{345}$ reveals something very interesting about the bankruptcy estate. The trustee does not

Judge Gould seems to have misunderstood this argument; he took $A$ to be arguing that "any violation of the automatic stay instituted in the Chapter 11 case becomes irrelevant once the case is converted to Chapter 7." In re Stanton, 303 F.3d at 949 . Judge Gould relied on two cases to show that $A$ 's advance was void as a violation of the automatic stay. Yet the two cases cited undermine, not aid, Judge Gould's position.

In British Aviation Insurance Co. v. Menut (In re State Airlines, Inc.), 873 F.2d 264 (11 th Cir. 1989), $C$ was injured in an airplane crash. $D$ then filed for chapter 11 protection. Id. at 265. $C$ obtained relief from the automatic stay. $I d$. at 265-66. D's case was converted to chapter 7 . $I d$. at 266. D's insurer claimed that the conversion order reinstituted the automatic stay. Id. The court disagreed: the lifting of the stay survived conversion of the case and $C$ was free to proceed outside bankruptcy court. Id. at 269.

In Johnson v. Garden State Brickface $\mathcal{E}$ S Stucco Co., 150 B.R. 617 (E.D. Pa. 1993), the court concluded that $\S 362$ (a) never applies to $D$ 's postpetition tort victims. This is, by the way, an extremely questionable holding. In any case, it hardly supports Judge Gould's position. Quite the opposite is true. Johnson suggests that the automatic stay never affects postpetition claims at all.

3453 F.2d 939 (9th Cir. 2002), aff'g 248 B.R. 823 (B.A.P. 9th Cir. 2000). 
own the debtor's prepetition property straight out. The trustee only has a lien on it. For this reason, a debtor always has a valid postpetition transfer to make. The debtor owns a surplus right to the bankruptcy estate under $\S 726$ (a) (6). Section 549(a) avoidance can never apply to undo this conveyance simply because the surplus is beyond the estate, and no conveyance of it can adversely affect the bankruptcy trustee. 